Article

\title{
How Delayed is "Delayed Integration"? Estimating Transitions out of Unemployment Spells Using Discrete-Time Survival Models
}

\author{
Oxana Krutova ${ }^{1, *}$ and Tapio Nummi ${ }^{2}$ \\ 1 School of Social Sciences and Humanities, University of Tampere, 33100 Tampere, Finland \\ 2 School of Information Sciences, University of Tampere, 33100 Tampere, Finland; Tapio.Nummi@uta.fi \\ * Correspondence: Oxana.Krutova@staff.uta.fi; Tel.: +358-504-312-534
}

\begin{abstract}
This paper studies the duration patterns of unemployment spells for immigrants and the determinants of unemployment's completion into one of a number of studied labour market states in Finland. We estimate a duration model for unemployment with competing risks of its terminating into employment, labour market training or economic inactivity. Taking into account the wide period of observation and opportunities to analyse processes of labour market integration during various periods of economic development in Finland, in combination with the individualistic character of the labour careers of immigrants, this research is beneficial owing to the many various findings concerning labour market integration of immigrants. The approach undertaken in this research has a dualistic "descriptive-dynamic" character under which integration is understood as a never-ending process, which is conditioned by a time period of long-term existence and a context of solitary action. We find that transitions out of unemployment spells have a cyclical character; after every new "cycle" in unemployment, the probability of terminating unemployment decreases further. We also find that ascriptive factors make sense in the process of job-placement of immigrants from unemployment. Therefore, the gender, education and age of immigrants, as well as the effect of the period in which first unemployment occurred, potentially predict transitions out of unemployment and further labour market integration of immigrants.
\end{abstract}

Keywords: discrete-time hazard models; labour market transitions; duration of unemployment spells; immigration

\section{JEL classifications: C41}

\section{Introduction}

In the 1960s and 1970s, unemployment became the major threat to societal order and economic growth, especially in areas that were more vulnerable to unstable economic development. Economic recession in the 1960s thus created an incentive to revise employment policy in Finland. For example, the number of participants in employment policy measures quadrupled during the two recessions in the years 1973-75 and 1977-80, when the focus of Finnish active labour market policy was shifted towards selective employment measures. Already in the 1980s, Finland had become one of a few European countries with rather low unemployment rates, well-developed corporatist bargaining structures and active labour market policies. The economic boom in Finland lasted until the 1990s. Like many European countries at the beginning of the 1990s, the national economy of Finland fell into a period of economic stagnation. In this period, corporatist labour market institutions, which had been effective in the years prior, proved to be ineffective as unemployment rates significantly increased from $3.5 \%$ to $18 \%$ during the years 1990-1993 [13, 16, 17, 20]. The lowest point of the economic depression had passed by the end of 1992, however, and the government began to restore sustainable economic growth and improve the employment situation. 
Yet, in Finland, the improved economic situation has not been reflected in the number of people in the "hard-to-employ" groups. At the end of May 2016, the number of long-term unemployed people who had been unemployed without interruption for more than a year amounted to 125,000 , up by 19,500 as compared to the previous year. Long-term unemployed people who had been unemployed without interruption for more than two years numbered 55,900, 9,100 more than the previous year (sources: Employment Service Statistics from the Ministry of Employment and the Economy, www.findikaattori.fi). This has been caused by decreased demand for labour, a reduction in the available labour policy measures and tightened access to unemployment pensions since 2010.

The dynamics of the labour market in Finland still has an ambiguous character. On the one hand, transition to economic inactivity remains one of the most typical features of unsuccessful adaption to labour market conditions and more than $10 \%$ of unemployed people do not realize transitions between statuses within the labour market and outside it. On the other hand, an overwhelming majority of the population realizes only one transition during a two-year period. In most cases, these transitions involve the move from "outside the labour market to employment" and "unemployment to employment" [22] (pp. 54-56), [15] (pp. 58-59). The dimensions of integrative capacity can be various: from the system of integrative, maintenance and exclusionary transitions in the labour market [23] to the employment quality concept [19], or to the unemployment quality concept [25]. If quality of employment concerns mainly full-time/part-time employment, over-qualification, temporary employment and self-employment, quality of unemployment primarily involves indicators of long-term, structural unemployment and specificity of the transition realized by unemployment spells.

The existing literature contains multiple approaches to estimation of duration of unemployment and transitions to other exit states. Many empirical studies using discrete-time hazard models on the topic of transitions out of unemployment spells have been published, some of which use a very restricted model specification. Thus, Bover and Gómez [6], Güell and Petrongolo [11], Gesthuizen and Wolbers [10] and Wolbers [31] find importance of educational background in transitions from unemployment to employment. Alba-Ramírez et al. [3], Böheim and Taylor [7] and Güell and Petrongolo [11] emphasize the significance of gender in transitions out of unemployment spells and continuity of unemployment. Müller and Steiner [21], Steiner [26] and Tatsiramos [27] find that effects of unemployment benefit sanctions on re-employment probabilities are gender-determined. On the other hand, Blau and Riphahn [4] and de Graaf and Ultee [9] come to a conclusion regarding the significance of age in transitions out of unemployment spells. Based on conventional continuous time duration models, Addison and Portugal [1], Caliendo et al. [8], Bover et al. [5] and Bover and Gómez [6] find that duration of unemployment benefits is exclusively age-determined. Finally, Uhlendorff and Zimmermann [30] and Hagen [12] come to the conclusion that, compared to natives, unemployed migrants do not find less stable positions but they require more time to find a job. Thus, migrants remain unemployed for longer than natives, but the probability of leaving unemployment differs strongly with ethnicity.

The statistics provided by Statistics Finland demonstrate the existence of essential differences between the unemployed native population and unemployed immigrants in Finland. For example, until 2013, the labour force in Finland numbered 2.5 million people and the share of unemployed persons in the overall structure of the labour force came to 301,000 people. Comparatively, the labour force of the immigrant population totalled only 106,730 people, or $4.2 \%$ of the overall quantity of the labour force. The share of the unemployed population in the overall structure of the labour force among the immigrant population amounted 27,000 people, totalling $8.9 \%$ of the overall share of the unemployed population of Finland. Comparing the proportions of labour force and unemployed population among the native population and immigrants in 2013, the unemployment rate of the native population came to $11.9 \%$, whereas for immigrants it was $25.3 \%$ (calculations based on the Employment database of Statistics Finland for 2013). 
The method of calculating unemployment used by the Ministry of Employment and the Economy implies analysis of the flows of unemployment during a fixed yearly period. According to the Ministry's statistics, unemployment ends for one of four reasons: "job-placement", "relocating to an employment policy measure", "labour market training" or "moving to economic inactivity". This method implies that a period of observation includes all the periods of unemployment, even though every unemployed person can have several periods of unemployment during the whole year (less than three months, from six to 12 months, etc.). Consequently, a person can be counted in the database as "unemployed" several times within one year. The cumulative character of this method of counting is thus obvious [24].

Following multiple studies in the sphere of transitions out of spells of unemployment, we here attempt to estimate real-time determinants of completion of unemployment periods and look for an answer to the following research questions: "do time constraints of completed unemployment periods differ depending on reasons for termination of unemployment periods? Do individual characteristics of unemployed people potentially affect the time of completion of unemployment and exit states, to which transitions from unemployment are realized?" In this paper we study time determinants and individual (socio-demographic) determinants of transitions out of unemployment. We estimate a duration model of unemployment using the URA-database gathered by the Ministry of Employment and the Economy for the period between the years 1952 and 2014 . We believe that duration models best describe the dynamics of the process of transition out of unemployment. Using STATA 12.0 software, we exploit the strength of longitudinal data, which allow us to follow the careers of immigrants over time. The paper is organized as follows. Section 2 describes the data set used and illustrates the econometric model proposed for analysis. Section 3 presents the results. Section 4 discusses basic research results. Section 5 and Section 6 contain, respectively, the bibliography and additional material in the form of an appendix.

\section{Data and methods}

\subsection{Data}

The data were collected from the URA-database, which are the employment services' system data provided by the Ministry of Employment and the Economy in Finland. This system provides information about labour force and entrepreneurship services in Finland. The database contains information about the employment-seeking population as codes of employment (employment, unemployment, economic inactivity, etc.) and the changes in these codes in terms of the beginning and ending of unemployment, as well as apprenticeship periods. There is no prearranged, ready for analysis data sets in the URA-database. The Ministry instead aggregates information for each individual case by selecting the data according to specific research aims. The URA-database is allencompassing, containing information about all unemployed people who have been registered with employment services in Finland. Therefore, all information concerning programmes of adaptation for Finland's unemployed population is also available in the URA-database.

Based on this study's research aims, only immigrants who have been registered in the URAdatabase as part of the "unemployed population" and, consequently, obtained a right to participate in programmes of adaptation for unemployed persons initiated by the government of Finland have been chosen for the present study. The sample includes immigrants who entered employment during the years of the study period. An analysis of integration processes for unemployed immigrants should be based on the following basic data concerning jobseekers: personal data, beginning and ending of employment periods, employment situation, work histories, educational degrees and adult education in the course of labour force policy measures or necessity of additional apprenticeships. The research database also contains information regarding measures for job-placement of jobseekers and offers of jobs, apprenticeships or retraining.

The observation period, which has been taken as the basis for research in the form of duration analysis, implies careful description of results conforming to a period of first unemployment experienced by immigrants (the so-called "entrance cohort"). Due to this specific observation period, 
the study implies an explanation of results from the position of the cohort analysis that is necessary in the case of extensive longitudinal databases. The factor of belonging to an entrance cohort demonstrates one's worth as the most ponderable factor of influence upon intensity of transitions from and to unemployment. Other immigrant jobseekers of later entrance cohorts potentially have greater opportunity for more transitions than do representatives of earlier cohorts. However, one can explain this circumstance by reference to the fact that the observation period covers the years 19522014, and thus periods of unemployment can be registered in the database in two ways. The first is based on the registration of the overall unemployment period, for which the beginning of a first period and the end of a last period are known. For example, earlier entrance cohorts can be registered as cohorts "1952-1961", "1962-1971" and "1972-1981"). The second way is based on the principle that, for later entrance cohorts, every period of unemployment is fixed separately (that is more believable). For example, the cohorts "1982-1991", "1992-2001" and "2002-2014" can be registered in this way. In this case, either the unemployment periods registered in the URA-database are in fact real, or these registrations are admittedly composed in two ways.

For each unemployment spell, the duration of the spell and the reason for its termination are recorded. We only observe whether individuals leave unemployment within one-month intervals. The length of an unemployment period is, therefore, assumed to be a discrete random variable. We are interested in the duration of unemployment and the states that follow, or destinations. Given the nature of the underlying data, we use methods applicable to discrete duration data. We estimate the time dependence of each transition simultaneously, allowing each transition to have individual time patterns and to be differently affected by the covariates. Our sample consists of unemployment durations and unemployment spells that terminate due to employment or other reasons. Thus, individuals are only followed from January 1952 up to December 2014, and ongoing spells at that latter date are interval-censored. This means that we know when a first unemployment period has been recorded and when a last unemployment period has ended in the URA-database. This enables us to treat these data as (discrete-time) duration data. Hence, we can analyse the time spent in unemployment and we can distinguish between eight subsequent destination states, characterized as employment, labour market training and non-participation (Table 1). General descriptions of variables used in the analysis are given in Table A1 in Appendix A.

Table 1. The distribution of state of exit of unemployment spells and their durations $(\mathrm{N}=16,166)$.

\begin{tabular}{|c|c|c|c|c|c|c|c|c|c|}
\hline 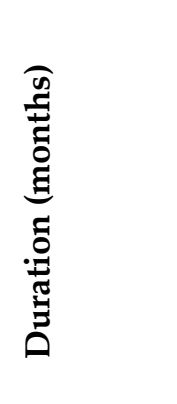 & 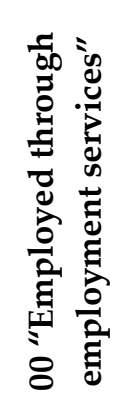 & 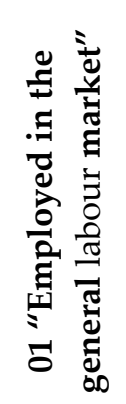 & 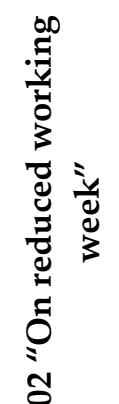 & 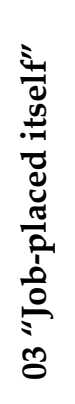 & 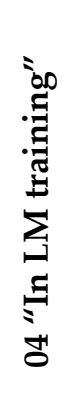 & 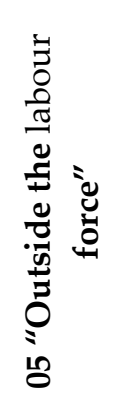 & 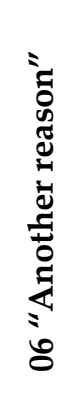 & 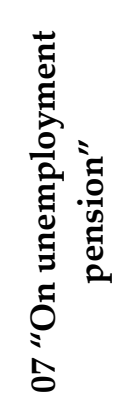 & 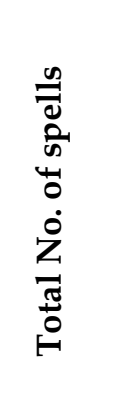 \\
\hline-3 & 1,999 & 410 & 4,199 & 131 & 67 & 82 & 35 & 215 & 7,138 \\
\hline-6 & 783 & 304 & 1,698 & 10 & 63 & 22 & 45 & 120 & 3,045 \\
\hline 12 & 519 & 401 & 1,039 & 4 & 74 & 35 & 34 & 148 & 2,254 \\
\hline 13-24 & 239 & 450 & 287 & 3 & 91 & 43 & 53 & 140 & 1,306 \\
\hline$>25$ & 441 & 1,022 & 199 & 10 & 160 & 91 & 115 & 385 & 2,423 \\
\hline $\begin{array}{l}\text { otal No. } \\
\text { f spells }\end{array}$ & 3,981 & 2,587 & 7,422 & 158 & 455 & 273 & 282 & 1,008 & 16,166 \\
\hline
\end{tabular}


According to estimations in Table 1, a considerable share - approximately $46 \%$ - of the unemployment spells ended in job-placement on a reduced working week. Two other exit states are also found to be considerable: approximately $25 \%$ of unemployment spells ended in job-placement through employment services, while $16 \%$ of unemployment spells ended in job-placement in the general labour market. In general, more than $87 \%$ of unemployment spells are completed by reason of job-placement in one of these three forms (exit states 00-03). Table 2 also provides information on random samples of 7,669 spells for males and 8,497 spells for females. A majority of immigrants have upper secondary education $(39.9 \%)$. The same tendency is clear when analysing completing unemployment spells that end in one of the studied exit states: a majority of job-placed immigrants have upper secondary education.

Table 2. Descriptive statistics on 'exit states' and main explanatory variables as applied to DiscreteTime Data $(\mathrm{N}=16,166)$.
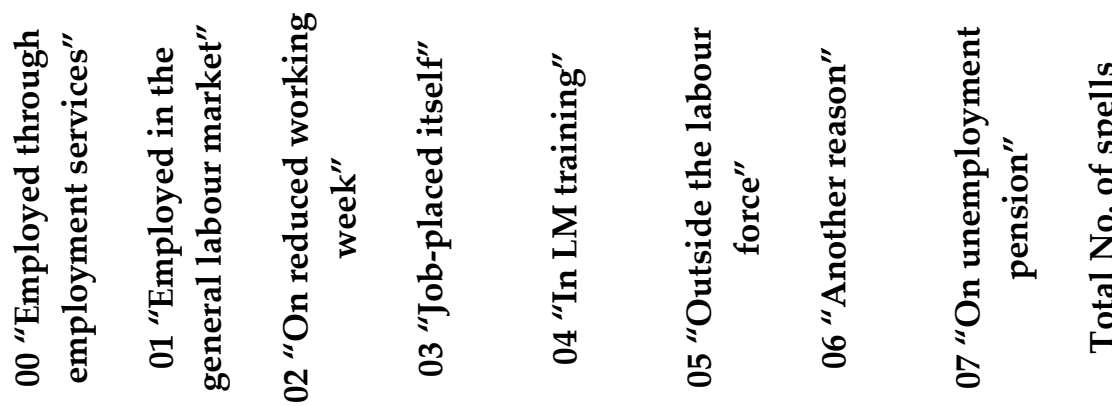

$\begin{array}{crr}\text { Man } & 2,028 & 1,233 \\ \text { Woman } & 1,953 & 1,354\end{array}$

\section{Gender:}

$\begin{array}{lllllll}3,220 & 88 & 293 & 157 & 163 & 487 & 7,669 \\ 4,202 & 70 & 162 & 116 & 119 & 521 & 8,497\end{array}$

$\begin{array}{ccc}\text { Early education } & 0 & 1 \\ \text { Primary education } & 249 & 93 \\ \text { Lower secondary } & 610 & 369 \\ \text { Upper secondary } & 1,551 & 1,085 \\ \text { Short-cycle } & 442 & 298 \\ \text { tertiary } & & \\ \text { Bachelor or equiv. } & 352 & 308 \\ \text { Master or equiv. } & 419 & 263 \\ \text { Doctoral or equiv. } & 48 & 21 \\ \text { Not classified } & 310 & 149 \\ & & \\ \text { 1935-1946 } & 315 & 292 \\ \text { 1947-1956 } & 719 & 504 \\ \text { 1957-1966 } & 1,262 & 831 \\ \text { 1967-1976 } & 1,241 & 784 \\ \text { 1977-1986 } & 444 & 176 \\ & & \\ \text { 1952-1961 } & 70 & 124 \\ 1962-1971 & 247 & 266 \\ \text { 1972-1981 } & 598 & 558 \\ \text { 1982-1991 } & 1,188 & 897 \\ \text { 1992-2001 } & 1,610 & 707 \\ 2002-2014 & 268 & 35\end{array}$

\section{Education:}

Educa
466
914
2,914
712

0

0

0

12

43
73

26

0

$\begin{array}{cc}0 & 1 \\ 37 & 954 \\ 141 & 2,216 \\ 408 & 6,465 \\ 108 & 1,674\end{array}$

$758 \quad 11$

949

126

583

\section{Birth-cohort:}

$\begin{array}{ccccccc}582 & 4 & 46 & 59 & 22 & 164 & 1,484 \\ 1,554 & 16 & 75 & 52 & 37 & 163 & 3,120 \\ 2,483 & 35 & 165 & 66 & 96 & 321 & 5,259 \\ 2,134 & 73 & 132 & 63 & 111 & 289 & 4,827 \\ 669 & 30 & 37 & 33 & 16 & 71 & 1,476\end{array}$

\section{Entrance-cohort:}

$\begin{array}{ccccccc}96 & 1 & 10 & 29 & 8 & 61 & 399 \\ 373 & 6 & 22 & 33 & 14 & 109 & 1,070 \\ 1,022 & 10 & 52 & 37 & 34 & 201 & 2,512 \\ 2,489 & 51 & 186 & 70 & 123 & 333 & 5,337 \\ 2,917 & 80 & 173 & 96 & 93 & 280 & 5,956 \\ 525 & 10 & 12 & 8 & 10 & 24 & 892\end{array}$


Two distinctive features concerning birth cohorts' structure emerged: the majority of immigrants belong to birth cohorts "1957-1966" (32.5\%) and "1967-1976" (29.8\%). On the other hand, the majority of immigrants belong to such entrance cohorts as "1982-1991" (33\%) and "1992-2001" (36.8\%). So, we are interested in the extent to which some observed characteristics of individuals may explain the time they spend in unemployment and where they go subsequently. Therefore, in the empirical analysis, we use a set of explanatory variables. The dependent variable in the study is, therefore, the number of months the individual spends in unemployment and the subsequent destination state. In addition to parameters that account for duration dependence defined over each one-month interval, the explanatory variables used in the analysis are gender, education, birth cohort and entrance cohort. A limited number of background characteristics relevant to the duration of unemployment are recorded for each spell.

\subsection{Econometric specification}

In the case of the present research, transitions out of unemployment spells are verified by means of discrete-time survival models, which are specified in terms of the discrete-time hazard and defined as the conditional probability that the event occurs in time $t$, given that it has not occurred. In general, each person should be represented by a row of data for each month the person was at risk. We therefore expand the data and create a new variable, "month", that labels the months per person. We use notation $\mathrm{T}$ for the time in months taken to exit from an unemployment spell, which can take integer values $t=1,2 \ldots \mathrm{k}$. If the variable "event" equals 1 , we know that $\mathrm{T}$ equals "months", and if "event" equals 0 , we know that $\mathrm{T}$ is greater than "months". Discrete-time survival models are specified in terms of the discrete-time hazard, defined as the conditional probability that the event occurs at time $t$, given that it has not yet occurred:

$$
h_{t} \equiv \operatorname{Pr}(T=t \mid T>t-1)=\operatorname{Pr}(T=t \mid T \geq t),
$$

The discrete-time survival function is the probability of not experiencing the event by time $t$ :

$$
S_{t} \equiv \operatorname{Pr}(T>t)
$$

For $\mathrm{t}=1$, this is simply 1 minus the probability that the event occurs at time 1 (given that it has not yet occurred, which is impossible), expressed as $S_{1}=\left(1-h_{1}\right)$. For $t=2, S_{2}$ is the probability that the event did not occur at time 1 and that it did not occur at time 2, given that it did not occur at time 1 , and can be expressed as $S_{2}=\operatorname{Pr}(T>2)=\operatorname{Pr}(T>2 \mid T>1) \operatorname{Pr}(T>1)=\left(1-h_{2}\right)\left(1-h_{1}\right)$. In general, we have:

$$
S_{t}=\prod_{s=1}^{t}\left(1-h_{s}\right)
$$

By expanding the data appropriately and defining a binary variable, $y$, taking values 0 and 1 , we obtain the estimated hazards as the proportions of 1 s observed each month. The response variable y should be 1 if an unemployment spell ended that month due to any of the eight studied reasons, and 0 otherwise. The data are now in person-month rather than person-period form (as in the case of general discrete-time models). In general, each person should be represented by a row of data for each month the person was at risk. We obtain estimated hazards as predicted probabilities by using a logistic regression model, where the covariates are dummy variables for each month:

$$
\operatorname{logit}\left\{\operatorname{Pr}\left(y_{s i}=1 \mid \mathrm{d}_{s i}\right)\right\}=a_{1}+a_{2} d_{2 s i}+\cdots+a_{k} d_{k s i}
$$

Here $y_{s i}$ is an indicator for the event occurring at time $s$ for person $\mathrm{i} ; \mathrm{d}_{2 \mathrm{si}} \ldots \mathrm{d}_{\mathrm{ksi}}$ are dummy variable $\mathrm{s}$ for months $2-\mathrm{k}$; and $\mathrm{d}_{\mathrm{si}}=\left(\mathrm{d}_{2 \mathrm{si}} \ldots \mathrm{d}_{\mathrm{ksi}}\right)^{\prime}$ is a vector containing all the dummy variables for person i.

The likelihood calculated by binary regression models based on expanded data is just the required likelihood for discrete-time survival data, and the resulting predicted hazards are maximum likelihood estimates. To see this, we consider the required likelihood contribution for a person who was censored at time $\mathrm{t}$, which is just the corresponding probability $S_{t i} \equiv \operatorname{Pr}\left(T_{i}>t\right)$. This probability is given by 


$$
S_{t i}=\prod_{s=1}^{t}\left(1-h_{s i}\right),
$$

where $h_{s i}$ is the discrete-time hazard at time $\mathrm{s}$ for person $\mathrm{i}$. In the expanded database, someone who is censored at time $t$ is represented by a row of data for $s=1,2 \ldots t$ with $y=0$. The corresponding likelihood contributions from binary regressions are the model-implied probabilities of the observed responses, $\operatorname{Pr}\left(\mathrm{y}_{\mathrm{si}}=0\right)=\left(1-\mathrm{h}_{\mathrm{s}}\right)$, and these are simply multiplied together because the observations are taken as independent, giving the required likelihood contribution for discrete-time survival. For an unemployed person who completed an unemployment period at time $t$, the likelihood contribution should be:

$$
\operatorname{Pr}\left(T_{i}=t \mid T_{i}>t-1\right) \operatorname{Pr}\left(T_{i}>t-1\right)=h_{t i} \prod_{s=1}^{t-1}\left(1-h_{s i}\right)
$$

Such a person is represented by a row of data $s=1,2, \ldots, t$ with $y=0$ for $s \leq t-1$ and $y=1$ for $s=t$. The likelihood for binary regression is therefore $\operatorname{Pr}\left(\mathrm{y}_{1 \mathrm{i}}=0\right){ }^{*} \ldots{ }^{*} \operatorname{Pr}\left(\mathrm{y}_{\mathrm{t}-1, \mathrm{i}}=0\right){ }^{*} \operatorname{Pr}\left(\mathrm{y}_{\mathrm{ti}}=1\right)$, as required. We can interpret the logistic regression model as a linear model for the logit of the discrete-time hazard:

$$
\operatorname{logit}\left\{\operatorname{Pr}\left(y_{s i}=1 \mid \mathrm{d}_{s i}\right)\right\}=a_{1}+a_{2} d_{2 s i}+\cdots+a_{k} d_{k s i}=\operatorname{logit}\left\{\operatorname{Pr}\left(T_{i}=s \mid T_{i} \geq s, d_{s i}\right)\right\}
$$

Although we investigate how the marginal hazard evolves over time, the main purpose of survival analysis is usually to estimate the effects of covariates on the hazard. In this case, regression models are necessary. To allow for maximum interaction between the important regressors, we stratify our data with respect to gender, education, birth cohort and entrance cohort. We specify a logistic regression for the data with these four covariates,

$$
\operatorname{logit}\left\{\operatorname{Pr}\left(y_{s i}=1 \mid \mathrm{d}_{s i}, x_{i}\right)\right\}=a_{1}+a_{2} d_{2 s i}+\cdots+a_{k} d_{k s i}+\beta_{1} x_{1 i}+\beta_{2} x_{2 i}+\beta_{3} x_{3 i}+\beta_{4} x_{4 i}
$$

where $\mathrm{x}_{\mathrm{i}}=\left(\mathrm{x}_{1 i}, \mathrm{X}_{2 i}, \mathrm{x}_{3 i}, \mathrm{x}_{4 i}\right)^{\prime}$ is the vector of covariates. The first part of the linear predictor, a, determines the so-called baseline hazard - the hazard when the covariates $x_{i}$ are all zero. The model could be described as semiparametric because no assumptions are made regarding the functional form for the baseline hazard, whereas the effects of covariates are assumed to be linear and additive on the logit scale. The response variable y should be 1 if failure occurred (unemployment period ended) for the person that month, and 0 if the event is still censored (i.e., unemployment period has not been ended). A constant difference in the log odds corresponds to a constant ratio of the odds. For this reason, the model is often called a proportional odds model, not the ordinal logistic regression. The model is also referred to as a continuation-ratio logit model or sequential logit model because the logit can be written as:

$$
\begin{aligned}
\operatorname{logit}\left\{\operatorname { P r } \left(T_{i}=s \mid T_{i}\right.\right. & \left.\left.\geq s, \mathrm{~d}_{i}, x_{i}\right)\right\}=\ln \left\{\frac{\operatorname{Pr}\left(T_{i}=s \mid T_{i} \geq s, \mathrm{~d}_{i}, x_{i}\right)}{\operatorname{Pr}\left(T_{i}>s \mid T_{i} \geq s, \mathrm{~d}_{i}, x_{i}\right)}\right\} \\
& =\ln \left\{\frac{\operatorname{Pr}\left(T_{i}=s, T_{i} \geq s, \mathrm{~d}_{i}, x_{i}\right) / \operatorname{Pr}\left(T_{i} \geq s, \mathrm{~d}_{i}, x_{i}\right)}{\operatorname{Pr}\left(T_{i}>s, T_{i} \geq s, \mathrm{~d}_{i}, x_{i}\right) / \operatorname{Pr}\left(T_{i} \geq s, \mathrm{~d}_{i}, x_{i}\right)}\right\} \\
& =\ln \left\{\frac{\operatorname{Pr}\left(T_{i}=s, T_{i} \geq s, \mathrm{~d}_{i}, x_{i}\right)}{\operatorname{Pr}\left(T_{i}>s, T_{i} \geq s, \mathrm{~d}_{i}, x_{i}\right)}\right\}=\ln \left\{\frac{\operatorname{Pr}\left(T_{i}=s \mid \mathrm{d}_{i}, x_{i}\right)}{\operatorname{Pr}\left(T_{i}>s \mid \mathrm{d}_{i}, x_{i}\right)}\right\}
\end{aligned}
$$

This model assumes that the difference in log odds between individuals with different covariates is constant over time. We obtain the estimated odds ratios associated with the four covariates by exponentiating the coefficients. We obtain the estimated hazards $\hat{h}_{s i}$ from the log odds. To get the cumulative products $S_{t}=\prod_{s=1}^{t}\left(1-h_{s}\right)$ for each person, we use the relationship:

$$
\hat{\mathrm{S}}_{t i}=\prod_{s=1}^{t}\left(1-\hat{\mathrm{h}}_{s i}\right)=\exp \left\{\sum_{s=1}^{t} \ln \left(1-\hat{\mathrm{h}}_{s i}\right)\right\}
$$

There are sometimes multiple types of absorbing events or multiple modes of failure. We distinguish between eight types of events (00-08). A separate discrete-time hazard can then be defined for each type of absorbing event. This situation is referred to as one of competing risks as the events are competing in the sense that a person experiencing one of these events is removed from the risk sets of all other events. Discrete-time hazard modelling for multiple absorbing events can proceed in 
a similar manner as for single events, with the difference being that the responses in the expanded data are nominal (with different categories of events) and no longer binary.

$$
\begin{aligned}
& \ln \left\{\frac{\operatorname{Pr}\left(z_{s i}=1 \mid \mathrm{d}_{i}, x_{s i}\right)}{\operatorname{Pr}\left(z_{s i}=0 \mid \mathrm{d}_{i}, x_{s i}\right)}\right\}=a_{1}^{[1]}+a_{2}^{[1]} d_{2 s i}+\cdots+a_{k}^{[1]} d_{k s i}+\beta_{1}^{[1]} x_{1 i}+\beta_{2}^{[1]} x_{2 i}+\beta_{3}^{[1]} x_{3 i}+\beta_{4}^{[1]} x_{4 i} \\
& \ln \left\{\frac{\operatorname{Pr}\left(z_{s i}=2 \mid \mathrm{d}_{i}, x_{s i}\right)}{\operatorname{Pr}\left(z_{s i}=0 \mid \mathrm{d}_{i}, x_{s i}\right)}\right\}=a_{1}^{[2]}+a_{2}^{[2]} d_{2 s i}+\cdots+a_{k}^{[2]} d_{k s i}+\beta_{1}^{[2]} x_{1 i}+\beta_{2}^{[2]} x_{2 i}+\beta_{3}^{[2]} x_{3 i}+\beta_{4}^{[2]} x_{4 i} \\
& \ln \left\{\frac{\operatorname{Pr}\left(z_{s i}=3 \mid \mathrm{d}_{i}, x_{s i}\right)}{\operatorname{Pr}\left(z_{s i}=0 \mid \mathrm{d}_{i}, x_{s i}\right)}\right\}=a_{1}^{[3]}+a_{2}^{[3]} d_{2 s i}+\cdots+a_{k}^{[3]} d_{k s i}+\beta_{1}^{[3]} x_{1 i}+\beta_{2}^{[3]} x_{2 i}+\beta_{3}^{[3]} x_{3 i}+\beta_{4}^{[3]} x_{4 i} \\
& \ln \left\{\frac{\operatorname{Pr}\left(z_{s i}=4 \mid \mathrm{d}_{i}, x_{s i}\right)}{\operatorname{Pr}\left(z_{s i}=0 \mid \mathrm{d}_{i}, x_{s i}\right)}\right\}=a_{1}^{[4]}+a_{2}^{[4]} d_{2 s i}+\cdots+a_{k}^{[4]} d_{k s i}+\beta_{1}^{[4]} x_{1 i}+\beta_{2}^{[4]} x_{2 i}+\beta_{3}^{[4]} x_{3 i}+\beta_{4}^{[4]} x_{4 i} \\
& \ln \left\{\frac{\operatorname{Pr}\left(z_{s i}=5 \mid \mathrm{d}_{i}, x_{s i}\right)}{\operatorname{Pr}\left(z_{s i}=0 \mid \mathrm{d}_{i}, x_{s i}\right)}\right\}=a_{1}^{[5]}+a_{2}^{[5]} d_{2 s i}+\cdots+a_{k}^{[5]} d_{k s i}+\beta_{1}^{[5]} x_{1 i}+\beta_{2}^{[5]} x_{2 i}+\beta_{3}^{[5]} x_{3 i}+\beta_{4}^{[5]} x_{4 i} \\
& \ln \left\{\frac{\operatorname{Pr}\left(z_{s i}=6 \mid \mathrm{d}_{i}, x_{s i}\right)}{\left.\operatorname{Pr}\left(z_{s i}=0 \mid \mathrm{d}_{i}, x_{s i}\right)\right\}=a_{1}^{[6]}+a_{2}^{[6]} d_{2 s i}+\cdots+a_{k}^{[6]} d_{k s i}+\beta_{1}^{[6]} x_{1 i}+\beta_{2}^{[6]} x_{2 i}+\beta_{3}^{[6]} x_{3 i}+\beta_{4}^{[6]} x_{4 i}}\right. \\
& \ln \left\{\frac{\operatorname{Pr}\left(z_{s i}=7 \mid \mathrm{d}_{i}, x_{s i}\right)}{\operatorname{Pr}\left(z_{s i}=0 \mid \mathrm{d}_{i}, x_{s i}\right)}\right\}=a_{1}^{[7]}+a_{2}^{[7]} d_{2 s i}+\cdots+a_{k}^{[7]} d_{k s i}+\beta_{1}^{[7]} x_{1 i}+\beta_{2}^{[7]} x_{2 i}+\beta_{3}^{[7]} x_{3 i}+\beta_{4}^{[7]} x_{4 i} \\
& \ln \left\{\frac{\operatorname{Pr}\left(z_{s i}=8 \mid \mathrm{d}_{i}, x_{s i}\right)}{\operatorname{Pr}\left(z_{s i}=0 \mid \mathrm{d}_{i}, x_{s i}\right)}\right\}=a_{1}^{[8]}+a_{2}^{[8]} d_{2 s i}+\cdots+a_{k}^{[8]} d_{k s i}+\beta_{1}^{[8]} x_{1 i}+\beta_{2}^{[8]} x_{2 i}+\beta_{3}^{[8]} x_{3 i}+\beta_{4}^{[8]} x_{4 i}
\end{aligned}
$$

The data are expanded so that unemployed persons are assigned 0 for every month in which none of the studied events occurred and 1 (for exit state 00), 2 (for exit state 01), etc., for each month in which unemployed persons complete a period of unemployment according to one of the eight studied reasons. In preparation for modelling multiple types of events, we then define a nominal variable $\mathrm{z}$ as "a reason according to which an unemployment period ends", taking a value of 0 until an event is experienced, 1 if the person moved to exit state 00, 2 if the person moved to exit state 01 , etc. We specify a logistic discrete-time hazard model for multiple absorbing events. The same covariates are used as those employed previously for the single-event case. Using the superscripts [1], ${ }^{[2]},{ }^{[3]} . . .{ }^{[8]}$ to denote the eight types of events, we specify a model with separate baseline hazards for each type of event.

\section{Results}

This section provides a concise and precise description of the experimental results, their interpretation and the experimental conclusions that can be drawn.

\subsection{General estimation of the econometric model}

We move to specify time frames of transitions out of unemployment spells to various exit states. As the basic research hypothesis, we assume that the time of completion of unemployment, hypothetically, predetermines an "outcome" of unemployment. The overall results of the research suggest that $87 \%$ of immigrants realize transitions from unemployment to one of the studied forms of employment - namely to employment through employment services, employment in the general labour market, job-placement on a reduced working week or self-employment. Therefore, the probability of transition from unemployment to employment in the general labour market has a growing tendency and achieves, towards the end of the observation period, the total-lot. This same tendency is peculiar to transitions from unemployment to labour market training or to unemployment pension.

Various studies confirm that job-placement is more effective during the first three months of unemployment; job-placement is one of the most likely reasons for completion of unemployment periods during this time. Another dynamic concerns unemployment periods lasting more than one year, when the share of those who have found a job essentially decreases. Consequently, an objective tendency proves that the probability of job-placement decreases in proportion to the duration of staying in unemployment. Admittedly, the longer unemployment lasts and the more episodes of 
unemployment an unemployed person has, the lesser their likelihood of being employed, in consequence. By analysing general tendencies, three important issues emerge: the time of completion of unemployment, transitions to employment or other statuses and overall time trends of transitions after three, six, 12 and 24 months in unemployment.

First, we obtain estimated hazards for transitions out of unemployment spells. The research results indicate that the estimated hazard of job-placement through employment services (exit state 00) reaches a maximum three times (in the interval "3-4 months", "6-7 months" and "12-13 months"). The cumulative failure function $1-S_{t}$ is usually estimated with the hazard function. Thus, at the end of the observation period, the cumulative failure comes to $69.7 \%$ (Fig. 1).

In comparison to employment through employment services, the estimated hazard for jobplacement with a reduced working week (exit state 02) also reaches a maximum three times (in the interval "3-4 months", "6-7 months" and "12-13 months"). At the end of the observation period, the cumulative failure for this "event" amounts to $64.2 \%$. On the other hand, the estimated hazard for employment in the general labour market (exit state 01 ) significantly changes during first 23 months of the observation period. Towards the end of the observation period, it comes to $96.7 \%$. However, the situation develops in another way if unemployed immigrants find a job themselves (exit state 03). As the number of those immigrants who were able to find a job themselves is rather small, this circumstance affects also the estimated hazard, which reaches a maximum in the interval "3-4 months" and then significantly declines to zero. The cumulative failure thus amounts only to $3.2 \%$ at the end of the observation period.

00 "Employed through employment services" $(69.77 \%)$

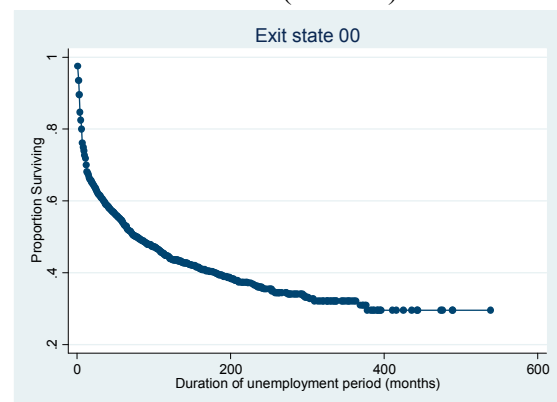

03 “Job-placed itself” (3.22\%)

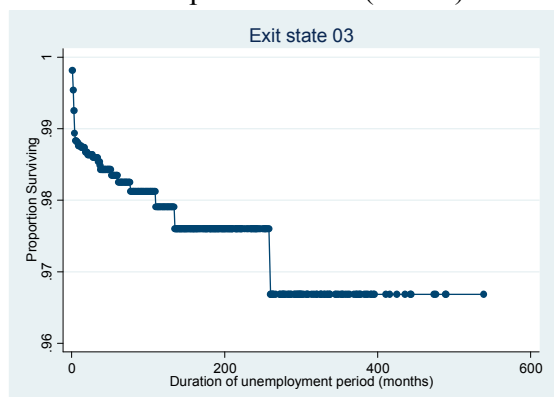

06 "Another reason" (33.63\%)

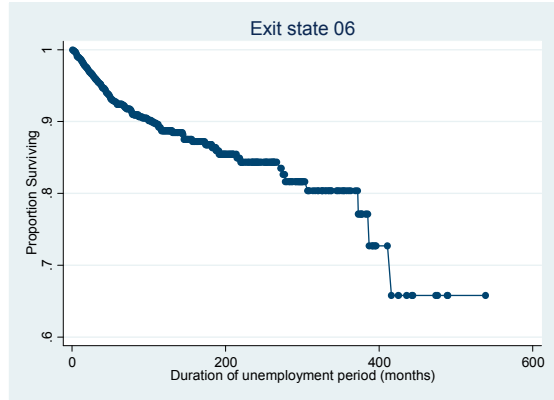

01 "Employed in the general labour market" $(96.75 \%)$

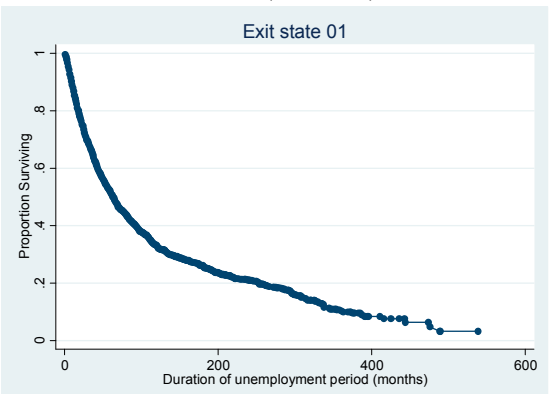

04 “In LM training” (100\%)

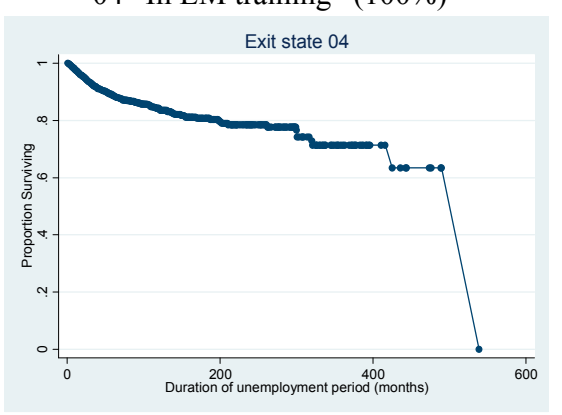

07 “On unemployment pension” (93.30\%)

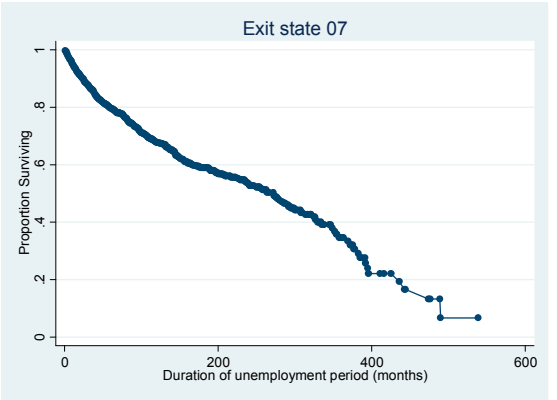

02 “On reduce working week" (64.23\%)

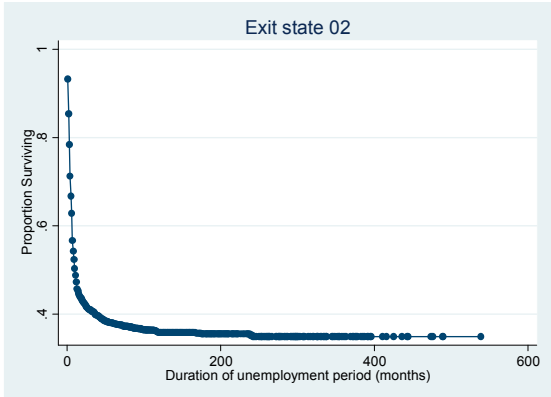

05 "Outside the labour force" (28.77\%)

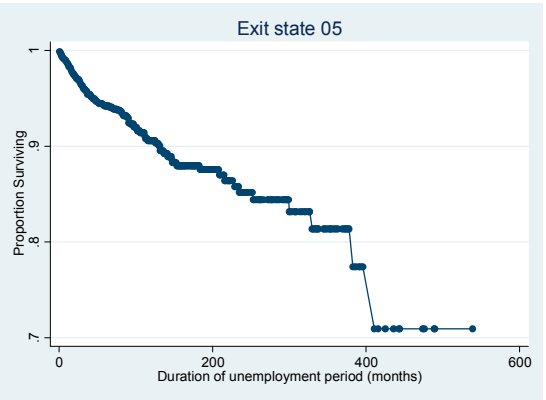

Figure 1. Proportion Surviving for eight exit states ( $N=16,166$ unemployment periods, in parentheses - cumulative failure of events). 
In contrast to these statuses concerning job-placement, transitions to other statuses have more manifold features. Firstly, the probabilities of transition to labour market training (exit state 04) are rather small in the beginning of the observation period, whereas these probabilities become more visible towards the end of the observation period, when the cumulative failure of allocation to labour market training achieves a $100 \%$ probability. Comparatively, transitions to economic inactivity from unemployment (exit state 05) also differ from other situations as the estimated hazard changes during the entire observation period and reaches a maximum at various time intervals. Towards the end of the observation period, the cumulative failure amounts to $28.7 \%$. Finally, the transitions to unemployment pension (exit state 07) have their own features. Transitions to this status from unemployment occur rather late, almost at the end of the observation period, when the cumulative failure comes to $93.3 \%$.

By analysing the situation in general, an additional aspect of the research includes a study of cumulative failures as limited by certain time periods, specifically three, six, 12 and 24 months after unemployment has ended. According to estimations, after three months of staying in unemployment, immigrants with a 50.3\% probability share are employed through employment services, while those with a $78.3 \%$ probability share are employed on a reduced working week (Fig. 2). With time, the probability of realizing transitions to one of these exit states increases by $18.7 \%$ for the exit state 00 "employed through employment services" and by $5.7 \%$ for the exit state 02 "on a reduced working week." On the other hand, the probability of employment in the general labour market comes to $12.5 \%$ after three months of continuous unemployment, whereas, after 24 months, this probability increases to $76.6 \%$.

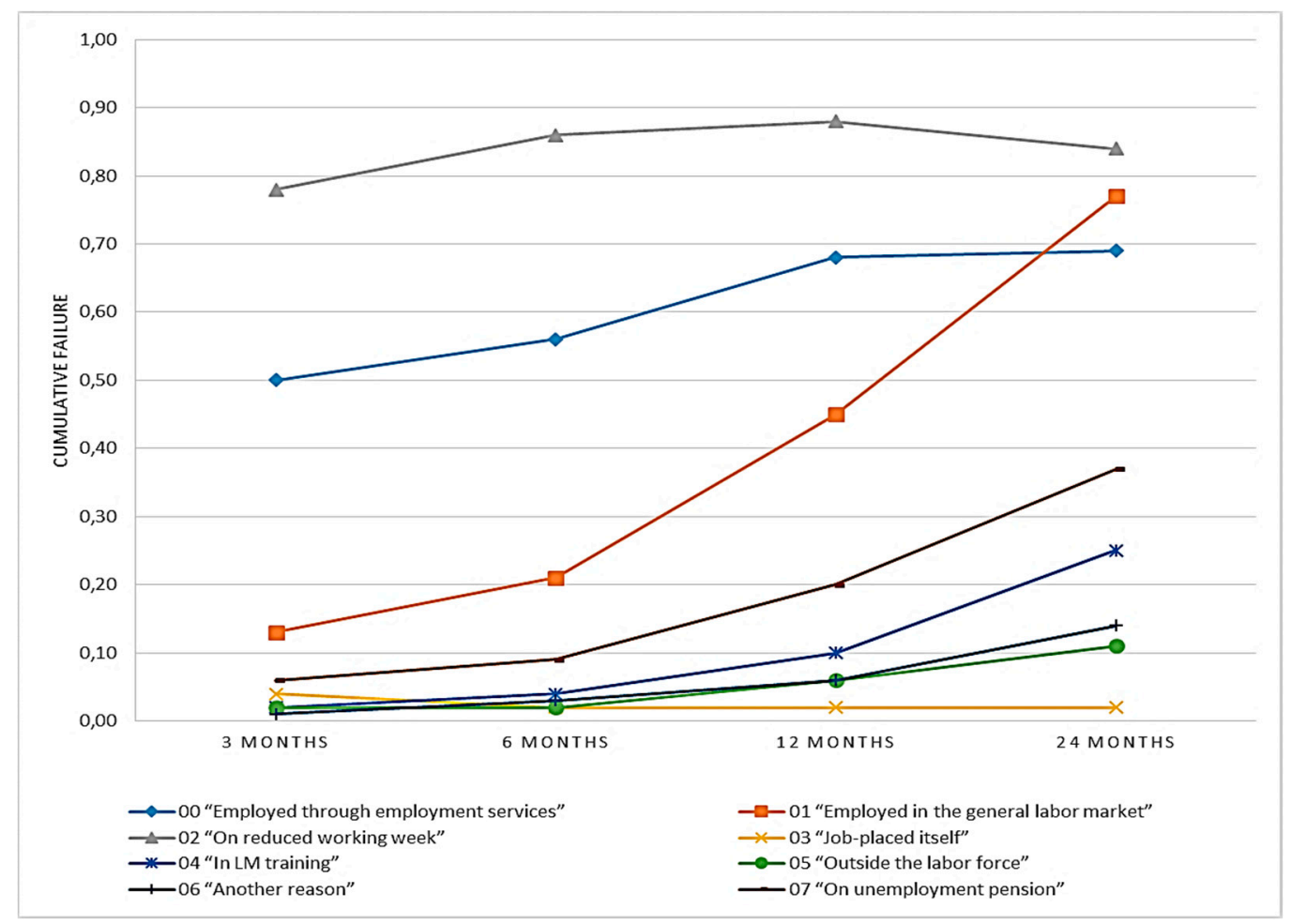

Figure 2. Cumulative failure for completed unemployment periods after 3, 6, 12, and 24 months (URA-database, $\mathrm{N}=16,166$ unemployment periods, period 1952-2014).

As the econometric model proposes, by expanding the data appropriately and defining a binary variable, $y$, we obtain the estimated hazards as the proportions of failures observed each month. The data expansion allows for the conducting of the most common type of discrete-time survival analysis. The results of our estimates are reported in Table 3. These estimates refer to the sample period 19522014, yet only the first 24 months of the observation period are taken into account as the basic period, during which intensity of transitions is the highest. In this case, we estimate the maximum likelihood 
for the response variable y and propose four models - three, six, 12 and 24 months - as separate regression models.

Table 3. The maximum likelihood estimates of the odds ratios for response variable y and timeconstant covariates for Models 1, 2, 3 and 4 representing various periods of observation - 3, 6, 12 and 24 months.

\begin{tabular}{|c|c|c|c|c|}
\hline $\begin{array}{l}\text { Time-constant covariates } \\
\text { month }\end{array}$ & Model 1 & Model 2 & $\begin{array}{l}\text { Model } 3 \\
\text { Ratio }\end{array}$ & Model 4 \\
\hline $\exp \left(\alpha_{2}\right)$ [month 2] & $1.15 * * *$ & $1.15 * * *$ & $1.15^{* * *}$ & $1.16 * * *$ \\
\hline $\exp \left(\alpha_{3}\right)[$ month 3] & $1.38 * * *$ & $1.38 * * *$ & $1.38 * * *$ & $1.39 * * *$ \\
\hline $\exp \left(\alpha_{4}\right)[$ month 4] & & $0.91 *$ & $0.91 *$ & $0.92 *$ \\
\hline $\exp \left(\alpha_{5}\right)[$ month 5] & & $0.87 * *$ & $0.87 * *$ & $0.87 * *$ \\
\hline $\exp \left(\alpha_{6}\right)[$ month 6] & & $1.46^{* * *}$ & $1.46^{* * *}$ & $1.47 * * *$ \\
\hline $\exp \left(\alpha_{7}\right)[$ month 7] & & & $0.65 * * *$ & $0.66 * * *$ \\
\hline $\exp \left(\alpha_{8}\right)[$ month 8] & & & $0.56 * * *$ & $0.56 * * *$ \\
\hline $\exp \left(\alpha_{9}\right)$ [month 9] & & & $0.62 * * *$ & $0.62 * * *$ \\
\hline $\exp \left(\alpha_{10}\right)$ [month 10$]$ & & & $0.54 * * *$ & $0.54 * * *$ \\
\hline $\exp \left(\alpha_{11}\right)$ [month 11] & & & $0.65 * * *$ & $0.65 * * *$ \\
\hline $\exp \left(\alpha_{12}\right)$ [month 12] & & & $0.72 * * *$ & $0.73 * * *$ \\
\hline $\exp \left(\alpha_{13}\right)$ [month 13] & & & & $0.31 * * *$ \\
\hline $\exp \left(\alpha_{14}\right)$ [month 14] & & & & $0.29 * * *$ \\
\hline $\exp \left(\alpha_{15}\right)$ [month 15] & & & & $0.33 * * *$ \\
\hline $\exp \left(\alpha_{16}\right)[$ month 16] & & & & $0.34 * * *$ \\
\hline $\exp \left(\alpha_{17}\right)$ [month 17] & & & & $0.28 * * *$ \\
\hline $\exp \left(\alpha_{18}\right)$ [month 18] & & & & $0.28 * * *$ \\
\hline $\exp \left(\alpha_{19}\right)$ [month 19] & & & & $0.28 * * *$ \\
\hline $\exp \left(\alpha_{20}\right)$ [month 20] & & & & $0.23 * * *$ \\
\hline $\exp \left(\alpha_{21}\right)$ [month 21] & & & & $0.22 * * *$ \\
\hline $\exp \left(\alpha_{22}\right)$ [month 22] & & & & $0.28 * * *$ \\
\hline $\exp \left(\alpha_{23}\right)$ [month 23] & & & & $0.24 * * *$ \\
\hline $\exp \left(\alpha_{24}\right)$ [month 24] & & & & $0.40 * * *$ \\
\hline $\exp \left(\beta_{1}\right)$ [gender $\left.\left(x_{I i}\right)\right]$ & $1.07 * *$ & $1.07 * *$ & $1.07 * * *$ & $1.05^{*}$ \\
\hline $\exp \left(\beta_{2}\right)$ [education $\left.\left(x_{2 i}\right)\right]$ & $0.98 * *$ & $0.98 * * *$ & $0.99^{\mathrm{ns}}$ & $0.98 *$ \\
\hline $\exp \left(\beta_{3}\right)\left[\right.$ birth cohort $\left.\left(x_{3 i}\right)\right]$ & $1.04 * *$ & $1.01^{\mathrm{ns}}$ & $0.99^{\text {ns }}$ & $1.01^{\mathrm{ns}}$ \\
\hline $\begin{array}{l}\exp \left(\beta_{4}\right) \text { [entrance cohort } \\
\left.\left(x_{4 i}\right)\right]\end{array}$ & $1.22 * * *$ & $1.26 * * *$ & $1.31 * * *$ & $1.31 * * *$ \\
\hline cons & $0.05 * * *$ & $0.04 * * *$ & $0.04 * * *$ & $0.04 * * *$ \\
\hline $\bar{L}$ Log likelihood & -15778.236 & -24747.982 & -32592.195 & -38137.739 \\
\hline N. of obs. & 39,455 & 63,662 & 93,497 & 130,332 \\
\hline
\end{tabular}

As can be seen from Table 3, the odds ratios on each of the 24 studied months are rather similar in each of four models. We turn to time-constant covariates as appropriate to each of the four models. As might be expected, being a woman, belonging to a more recent birth cohort and belonging to later entrance cohort are associated with a greater probability of completing unemployment spells (given that an unemployment spell has not yet ended), whereas higher levels of education are associated with decreased odds of completing unemployment spells. Regarding the coefficients of the dummy variables, their exponentials represent the odds ratio of completing unemployment spells in a given month (given that an unemployment spell has not yet ended) compared with month one, when $\mathrm{x}_{\mathrm{si}}=$ 0 . So, for instance, the odds of completing an unemployment spell are 1.39 times as great in month three and 1.47 times as great in month six as they are in month one, when all covariates take the value zero.

\subsection{Estimation of the econometric model for multiple absorbing events}

In our case, there are multiple types of absorbing events, or multiple modes of failure. In the unemployment statistics, eight types of exit states are classified, according to which unemployment 
ends. We define a separate discrete-time hazard for each absorbing event. These are referred to as competing risks as the events are competing in the sense that a person experiencing one of these events is removed from the risk sets of all other events. Comparing the influence of time-constant covariates upon transitions to one of eight exit states, one can see differences between the abovementioned influences, as presented in Table 3. In particular, without reference to a period, when an unemployment spell ends the significance of gender is greater for transitions to such exit states as 01 "employed in the general labour market", 02 "on a reduced working week" and 07 "on unemployment pension". The importance of education is greater for transitions to such exit states as 02 "on a reduced working week", 03 "job-placed oneself", 05 "outside the labour force" and 07 "on unemployment pension" (Table 4). Finally, belonging to a particular birth cohort is more significant for transitions to such exit states as 01 "employed in the general labour market" and 03 "job-placed oneself", whereas belonging to a particular entrance cohort is more important for such exit states as 02 "on a reduced working week".

Table 4. The maximum likelihood estimates of the odds ratios for response variables y1, y2 ... y8 and time-constant covariates for each of eight exit states $(\mathrm{N}=261,672)$.

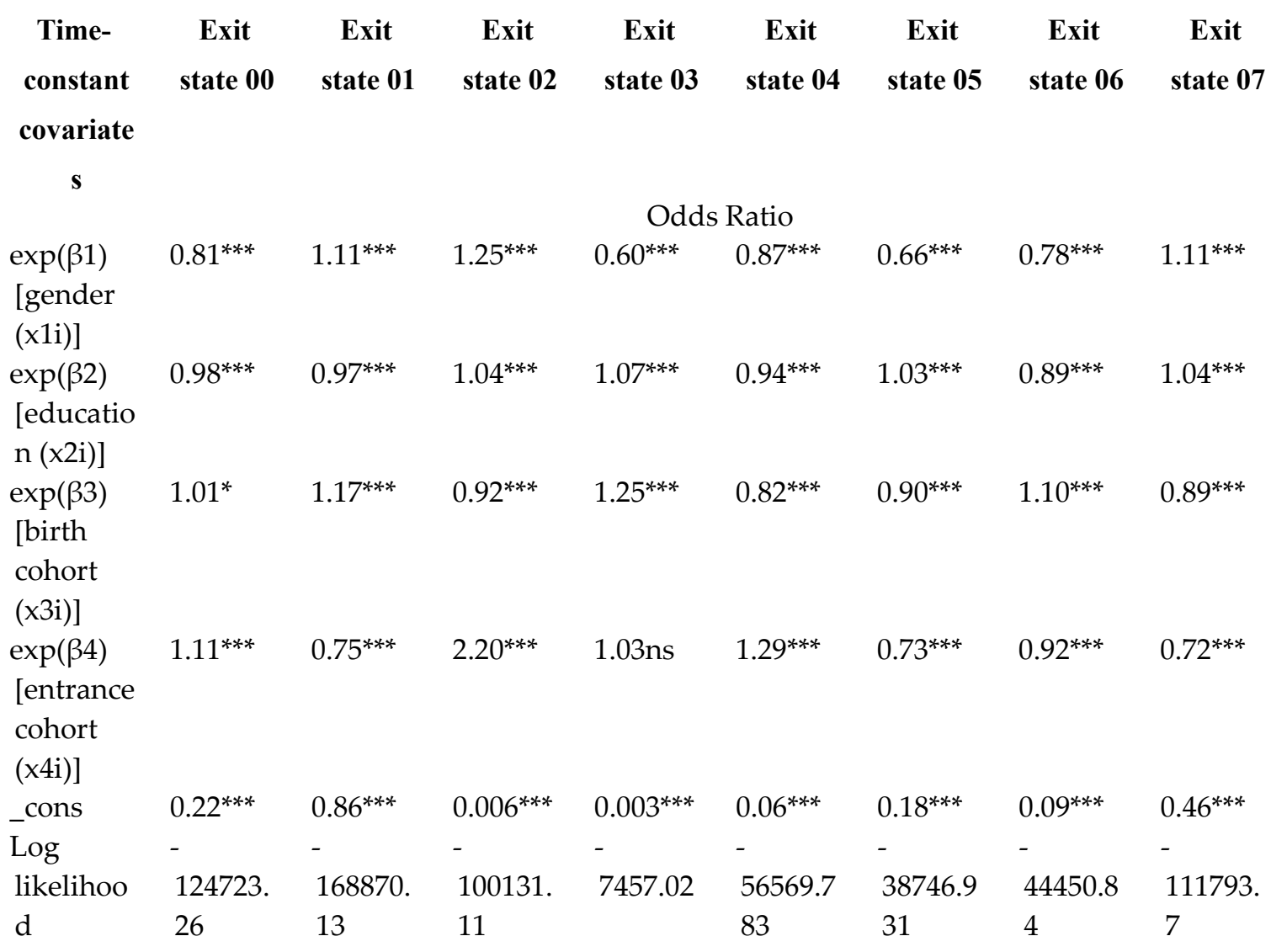

We proceed the discrete-time hazard modelling for multiple absorbing events in a similar manner as for single events (Table 4), with the difference that the responses in the expanded data are nominal (with eight categories of events) and no longer binary. The data are expanded so that persons are assigned zero for every month in which none of the events occurred and $1,2 \ldots 8$ for each month in which an unemployed person transitioned from unemployment according to one of the eight studied reasons, respectively. We fit a logistic discrete-time hazards model for multiple absorbing events by using the multinomial logit model for nominal responses. Table 5 contains estimations of relative risk ratios for time-constant covariates. 
Table 5. The maximum likelihood estimates of the relative risk ratios for response variable $\mathrm{z}$ "A reason, according to which an unemployment period ends" and time-constant covariates for each of eight exit states $(\mathrm{N}=261,672)$.

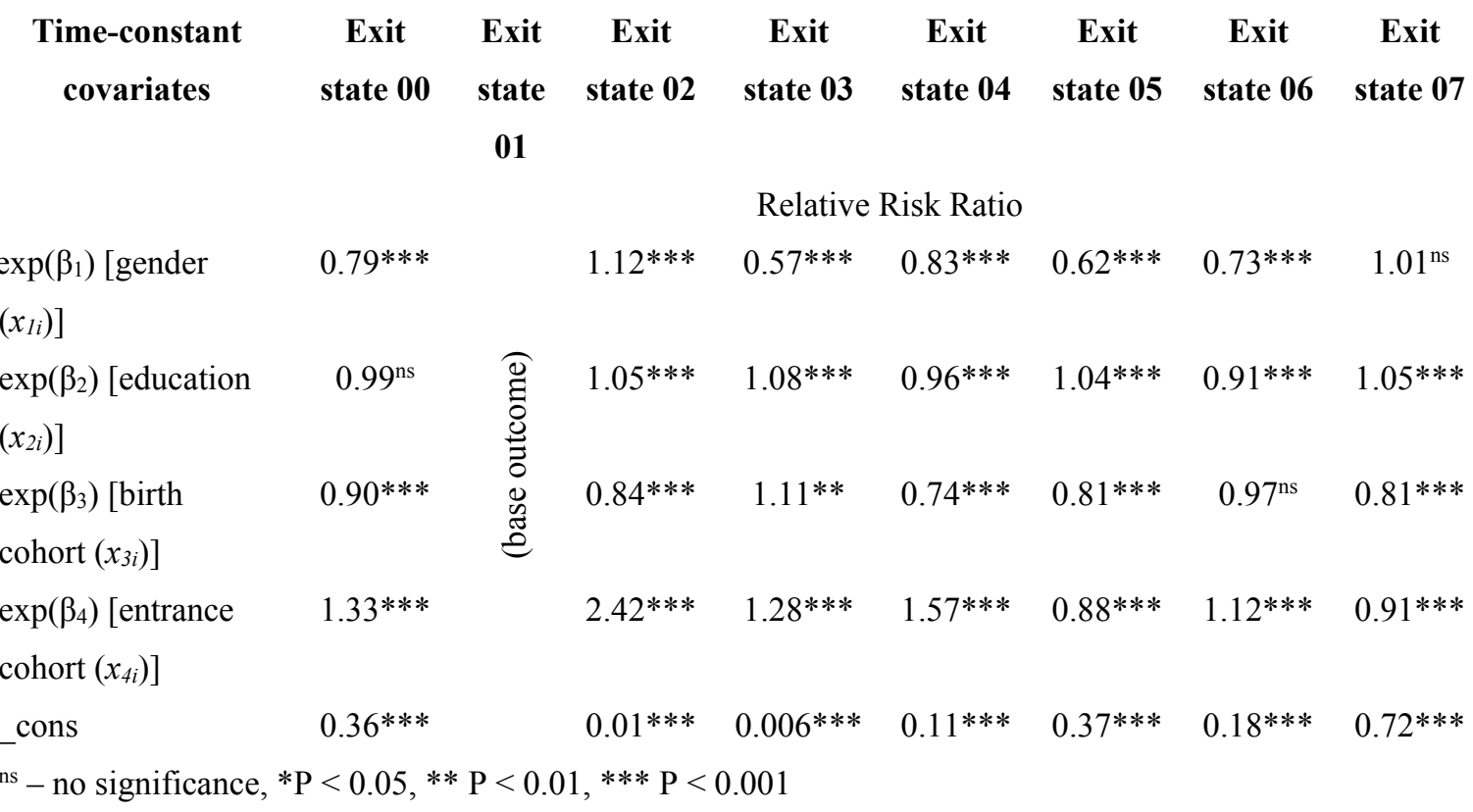

According to the estimations in Table 5, the estimated odds ratios for completing unemployment are generally not that different from those previously reported for the single-event case (Table 4). Regarding the estimated odds ratios for completing unemployment spells and transitioning to employment through employment services, a one-unit increase in birth cohort corresponds to a reduction in the odds of leaving unemployment by about $15 \%$, whereas a one-unit increase in entrance cohort corresponds to an increase in the odds of leaving unemployment by about $36 \%$, controlling for other covariates (Table 6).

Table 6. The maximum likelihood estimates of the relative risk ratios for response variable $\mathrm{z}$ "A reason, according to which an unemployment period ends", "month" and time-constant covariates for each of eight exit states ( $\mathrm{N}=130332)$.

$\begin{array}{ccccccccc}\text { Time-constant } & \text { Exit } & 01 & \text { Exit } & \text { Exit } & \text { Exit } & \text { Exit } & \text { Exit } & \text { Exit } \\ \text { covariates } & \text { state } & & \text { state 02 } & \text { state 03 } & \text { state 04 } & \text { state 05 } & \text { state 06 } & \text { state 07 } \\ & 00 & & & & & & & \end{array}$

Relative Risk Ratio

month

\begin{tabular}{|c|c|c|c|c|c|c|c|c|}
\hline \multirow[t]{2}{*}{$\exp \left(\alpha_{2}\right)$ [month 2] } & 0.82 & & $0.75^{*}$ & $0.63 *$ & $1.01^{\mathrm{ns}}$ & $0.89^{\mathrm{ns}}$ & $1.01^{\mathrm{ns}}$ & $0.95^{\mathrm{ns}}$ \\
\hline & $* * *$ & & $* *$ & $* *$ & & & & \\
\hline \multirow[t]{2}{*}{$\exp \left(\alpha_{3}\right)$ [month 3] } & 0.72 & & $0.64 *$ & $0.42 *$ & $1.00^{\mathrm{ns}}$ & $0.84^{\mathrm{ns}}$ & $1.02^{\mathrm{ns}}$ & $0.92^{\mathrm{ns}}$ \\
\hline & $* * *$ & छี & $* *$ & $* *$ & & & & \\
\hline \multirow[t]{2}{*}{$\exp \left(\alpha_{4}\right)$ [month 4] } & 0.60 & $\sigma$ & $0.53 *$ & $0.20 *$ & $1.04^{\mathrm{ns}}$ & $0.81 *$ & $1.06^{\mathrm{ns}}$ & $0.92^{\mathrm{ns}}$ \\
\hline & $* * *$ & $\begin{array}{l}\text {. } \\
\text { జ్ } \\
0\end{array}$ & $* *$ & $* *$ & & & & \\
\hline \multirow[t]{2}{*}{$\exp \left(\alpha_{5}\right)$ [month 5] } & 0.56 & & $0.46^{*}$ & $0.14 *$ & $1.02^{\mathrm{ns}}$ & $0.80^{*}$ & $1.09^{\mathrm{ns}}$ & $0.91^{\mathrm{ns}}$ \\
\hline & $* * *$ & & $* *$ & $* *$ & & & & \\
\hline \multirow[t]{2}{*}{$\exp \left(\alpha_{6}\right)$ [month 6] } & 0.51 & & $0.40 *$ & $0.15 *$ & $1.02^{\mathrm{ns}}$ & $0.82^{\mathrm{ns}}$ & $1.07^{\mathrm{ns}}$ & $0.89^{\text {ns }}$ \\
\hline & $* * *$ & & $* *$ & $* *$ & & & & \\
\hline
\end{tabular}




\begin{tabular}{|c|c|c|c|c|c|c|c|}
\hline \multirow[t]{2}{*}{$\exp \left(\alpha_{7}\right)$ [month 7] } & 0.42 & $0.29 *$ & $0.15^{*}$ & $1.04^{\mathrm{ns}}$ & $0.82^{\mathrm{ns}}$ & $1.04^{\mathrm{ns}}$ & $0.90^{\mathrm{ns}}$ \\
\hline & $* * *$ & $* *$ & $* *$ & & & & \\
\hline \multirow[t]{2}{*}{$\exp \left(\alpha_{8}\right)$ [month 8] } & 0.41 & $0.26^{*}$ & $0.15^{*}$ & $1.04^{\mathrm{ns}}$ & $0.83^{\mathrm{ns}}$ & $1.05^{\mathrm{ns}}$ & $0.90^{\mathrm{ns}}$ \\
\hline & $* * *$ & $* *$ & $* *$ & & & & \\
\hline \multirow[t]{2}{*}{$\exp \left(\alpha_{9}\right)$ [month 9] } & 0.40 & $0.23 *$ & $0.14^{*}$ & $1.06^{\mathrm{ns}}$ & $0.85^{\mathrm{ns}}$ & $1.08^{\mathrm{ns}}$ & $0.90^{\mathrm{ns}}$ \\
\hline & $* * *$ & $* *$ & $* *$ & & & & \\
\hline \multirow[t]{2}{*}{$\exp \left(\alpha_{10}\right)[$ month 10$]$} & 0.39 & $0.20 *$ & $0.14^{*}$ & $1.06^{\mathrm{ns}}$ & $0.85^{\text {ns }}$ & $1.11^{\mathrm{ns}}$ & $0.89^{\mathrm{ns}}$ \\
\hline & $* * *$ & $* *$ & $* *$ & & & & \\
\hline \multirow[t]{2}{*}{$\exp \left(\alpha_{11}\right)[$ month 11] } & 0.38 & $0.17 *$ & $0.15^{*}$ & $1.05^{\mathrm{ns}}$ & $0.84^{\mathrm{ns}}$ & $1.11^{\mathrm{ns}}$ & $0.89^{\text {ns }}$ \\
\hline & $* * *$ & $* *$ & $* *$ & & & & \\
\hline \multirow[t]{2}{*}{$\exp \left(\alpha_{12}\right)$ [month 12] } & 0.34 & $0.15^{*}$ & $0.16^{*}$ & $1.06^{\mathrm{ns}}$ & $0.83^{\text {ns }}$ & $1.12^{\text {ns }}$ & $0.88^{*}$ \\
\hline & $* * *$ & $* *$ & $* *$ & & & & \\
\hline \multirow[t]{2}{*}{$\exp \left(\alpha_{13}\right)[$ month 13] } & 0.31 & $0.12^{*}$ & $0.15^{*}$ & $1.07^{\mathrm{ns}}$ & $0.81^{\mathrm{ns}}$ & $1.13^{\text {ns }}$ & $0.88^{\mathrm{ns}}$ \\
\hline & $* * *$ & $* *$ & $* *$ & & & & \\
\hline \multirow[t]{2}{*}{$\exp \left(\alpha_{14}\right)[$ month 14$]$} & 0.31 & $0.12^{*}$ & $0.16^{*}$ & $1.05^{\mathrm{ns}}$ & $0.82^{\text {ns }}$ & $1.13^{\text {ns }}$ & $0.89^{\text {ns }}$ \\
\hline & $* * *$ & $* *$ & $* *$ & & & & \\
\hline \multirow[t]{2}{*}{$\exp \left(\alpha_{15}\right)[$ month 15$]$} & 0.31 & $0.11^{*}$ & $0.17^{*}$ & $1.06^{\mathrm{ns}}$ & $0.82^{\text {ns }}$ & $1.12^{\text {ns }}$ & $0.89^{\text {ns }}$ \\
\hline & $* * *$ & $* *$ & $* *$ & & & & \\
\hline \multirow[t]{2}{*}{$\exp \left(\alpha_{16}\right)[$ month 16$]$} & 0.30 & $0.11^{*}$ & $0.17 *$ & $1.06^{\mathrm{ns}}$ & $0.81^{\mathrm{ns}}$ & $1.14^{\mathrm{ns}}$ & $0.89^{\text {ns }}$ \\
\hline & $* * *$ & $* *$ & $* *$ & & & & \\
\hline \multirow[t]{2}{*}{$\exp \left(\alpha_{17}\right)[$ month 17] } & 0.30 & $0.10^{*}$ & $0.18^{*}$ & $1.04^{\mathrm{ns}}$ & $0.79^{\text {ns }}$ & $1.15^{\mathrm{ns}}$ & $0.89^{\text {ns }}$ \\
\hline & $* * *$ & $* *$ & $* *$ & & & & \\
\hline \multirow[t]{2}{*}{$\exp \left(\alpha_{18}\right)[$ month 18$]$} & 0.30 & $0.10^{*}$ & $0.16^{*}$ & $1.05^{\mathrm{ns}}$ & $0.78 *$ & $1.14^{\mathrm{ns}}$ & $0.89^{\text {ns }}$ \\
\hline & $* * *$ & $* *$ & $* *$ & & & & \\
\hline \multirow[t]{2}{*}{$\exp \left(\alpha_{19}\right)$ [month 19] } & 0.30 & $0.10^{*}$ & $0.16^{*}$ & $1.06^{\mathrm{ns}}$ & $0.78^{*}$ & $1.15^{\mathrm{ns}}$ & $0.89^{\text {ns }}$ \\
\hline & $* * *$ & $* *$ & $* *$ & & & & \\
\hline \multirow[t]{2}{*}{$\exp \left(\alpha_{20}\right)[$ month 20$]$} & 0.30 & $0.09 *$ & $0.17^{*}$ & $1.06^{\mathrm{ns}}$ & $0.77 *$ & $1.17^{\mathrm{ns}}$ & $0.90^{\mathrm{ns}}$ \\
\hline & $* * *$ & $* *$ & $* *$ & & & & \\
\hline \multirow[t]{2}{*}{$\exp \left(\alpha_{21}\right)[$ month 21$]$} & 0.30 & $0.09 *$ & $0.16^{*}$ & $1.07^{\mathrm{ns}}$ & $0.76^{*}$ & $1.16^{\mathrm{ns}}$ & $0.90^{\mathrm{ns}}$ \\
\hline & $* * *$ & $* *$ & $* *$ & & & & \\
\hline \multirow[t]{2}{*}{$\exp \left(\alpha_{22}\right)[$ month 22$]$} & 0.31 & $0.09 *$ & $0.16^{*}$ & $1.08^{\mathrm{ns}}$ & $0.77 *$ & $1.16^{\mathrm{ns}}$ & $0.90^{\mathrm{ns}}$ \\
\hline & $* * *$ & $* *$ & $* *$ & & & & \\
\hline \multirow[t]{2}{*}{$\exp \left(\alpha_{23}\right)[$ month 23$]$} & 0.31 & $0.09 *$ & $0.17 *$ & $1.08^{\mathrm{ns}}$ & $0.77 *$ & $1.16^{\mathrm{ns}}$ & $0.91^{\mathrm{ns}}$ \\
\hline & $* * *$ & $* *$ & $* *$ & & & & \\
\hline \multirow[t]{2}{*}{$\exp \left(\alpha_{24}\right)[$ month 24$]$} & 0.30 & $0.08 *$ & $0.17 *$ & $1.04^{\mathrm{ns}}$ & $0.77 *$ & $1.16^{\mathrm{ns}}$ & $0.91^{\mathrm{ns}}$ \\
\hline & $* * *$ & $* *$ & $* *$ & & & & \\
\hline \multirow[t]{2}{*}{$\exp \left(\beta_{1}\right)$ [gender $\left.\left(x_{I i}\right)\right]$} & 0.87 & $1.24 *$ & $1.03^{\mathrm{ns}}$ & $0.68^{*}$ & $0.69 *$ & $0.67 *$ & $1.01^{\mathrm{ns}}$ \\
\hline & $* * *$ & $* *$ & & $* *$ & $* *$ & $* *$ & \\
\hline $\exp \left(\beta_{2}\right)$ [education & $1.00^{\mathrm{n}}$ & $1.04 *$ & $1.06^{*}$ & $0.95 *$ & $0.95 *$ & $0.94 *$ & $1.03 *$ \\
\hline$\left.\left(x_{2 i}\right)\right]$ & $\mathrm{s}$ & $* *$ & $*$ & $* *$ & $* *$ & $* *$ & $* *$ \\
\hline $\exp \left(\beta_{3}\right)[$ birth cohort & 0.85 & $0.74 *$ & $1.23^{*}$ & $0.81 *$ & $0.82 *$ & $0.91 *$ & $0.86^{*}$ \\
\hline$\left.\left(x_{3 i}\right)\right]$ & $* * *$ & $* *$ & $* *$ & $* *$ & $* *$ & $* *$ & $* *$ \\
\hline
\end{tabular}




$\begin{array}{llllllll}\exp \left(\beta_{4}\right)[\operatorname{entrance} & 1.36 & 1.93 * & 1.23 * & 1.60 * & 0.93 * & 1.37^{*} & 1.01^{\mathrm{ns}} \\ \left.\text { cohort }\left(x_{4 i}\right)\right] & * * * & * * & * * & * * & * * & * * & \\ \text { _cons } & 0.88 & 0.28 * & 0.009 & 0.10 * & 0.48 * & 0.09 * & 0.47 * \\ & * & * * & * * * & * * & * * & * * & * * \\ & & & & & & & \end{array}$

Comparatively, estimating odds ratios for completing unemployment spells and job-placement on a reduced working week, a one-unit increase in birth cohort corresponds to a reduction in the odds by about $26 \%$, whereas a one-unit increase in entrance cohort corresponds to an increase in the odds of leaving unemployment by about $93 \%$, controlling for other covariates. So, for instance, the odds of completing unemployment spells are $50 \%$ smaller after month six for exit state 00 "employed through employment services" and are 50\% smaller after month four for exist state 02 "on a reduced working week" as compared to month one when all covariates take the value zero. Modelling and predicting transitions from unemployment to statuses of employment based on the discrete-time analysis confirms a hypothesis about the statistical regularity of job-placement processes for immigrants. For example, if a period of unemployment is completed, and transitions to such statuses as "job-placement through employment services" or "job-placement on a reduced working week" are equally time-directed, a transition from unemployment to regular employment occurs later and takes a longer time to be realized, which also testifies to its complicated character.

\subsection{Gender, education, birth cohort and entrance cohort in cumulative failures of absorbing events}

Estimating time-constant covariates as appropriate to different absorbing events, we come to significant differentiation of transitions out of unemployment spells depending on the distinct influences of gender, education, age and time of first becoming unemployed in Finland.

\subsubsection{Gender and transitions out of unemployment spells}

As concerns gender and its influence on employment through employment services, analysis shows that this probability is slightly higher for men than it is for women (the cumulative failure for men achieves $73.1 \%$, whereas for women it is $66.7 \%$ ). On the other hand, as concerns employment in the general labour market, this probability is almost the same for men as for women $(95.7 \%$ and $96.2 \%$, respectively). Finally, job-placement on a reduced working week occurs more frequently for women than for men (the cumulative failure for men comes to $61.9 \%$ and $66.2 \%$ for women).

As concerns transitions out of unemployment to other statuses, the research proves that the probability of taking up labour market training is higher for women than it is for men (the cumulative failure comes to $32.8 \%$ for men and $100 \%$ for women). In other cases, the probability of realizing a transition to one of the statuses not concerning job-placement is hypothetically higher for men than it is for women. For example, analysis of immigrants' gender and movement to economic inactivity shows that the cumulative failure for men is $36.3 \%$ and for women is $23.3 \%$. On the other hand, men and women realize transitions from unemployment to unemployment pensions with almost the same share of probability ( $100 \%$ for men and $91.8 \%$ for women).

\subsubsection{Education and transitions out of unemployment spells}

Analysis of employment through employment services based on the educational levels of unemployed immigrants shows that the probability of being employed through employment services is higher for immigrants having primary education $(71.7 \%)$, lower secondary education $(77.4 \%)$ and doctoral degrees $(72.5 \%)$. For other educational groups the cumulative failure accounts for between $62.1 \%$ and $69.3 \%$. By contrast, the maximal cumulative failure of employment in the general labour market is higher for immigrants having lower secondary education $(92.2 \%)$, upper secondary education $(94.3 \%)$ and a bachelor's degree (94.6\%). Significantly, however, immigrants with doctoral degrees have the smallest cumulative failure (66.4\%). Finally, the probability of job-placement on a reduced working week is higher for immigrants with a master's degree $(71.1 \%)$ or doctoral degree 
$(78.4 \%)$, whereas the minimal cumulative failure in this regard is peculiar to immigrants with shortcycle tertiary education (56.6\%).

Analysis shows that the probability of transition from unemployment to labour market training is the highest for immigrants with either primary education or a doctoral degree (both 100\%). For other educational groups the cumulative failure ranges between $18.5 \%$ and $65.2 \%$. Further, as concerns transitions from unemployment to economic inactivity, the probability of realizing such transitions is indicated to be higher for immigrants having short-cycle tertiary education $(61.6 \%)$, upper secondary education $(32.2 \%)$ or a doctoral degree (34.3\%). Finally, immigrants with lower secondary education, upper secondary education or a bachelor's degree (as well as immigrants without any education) realize more transitions to unemployment pension (the cumulative failure for each educational level being 100\%). Significantly, immigrants with doctoral degrees realize fewer transitions to unemployment pension (the cumulative failure being $13.6 \%$ ).

\subsubsection{Birth cohort, entrance cohort and transitions out of unemployment spells}

Basically, employment in the general labour market occurs with almost the same share of probability for all the birth cohorts (the cumulative failure varies between $91.3 \%$ and $100 \%$ ). On the contrary, employment through employment services is somewhat less likely and accounts for $73.5 \%$ to $82.4 \%$ for all the cohorts, except the cohort "1935-1946", for which the cumulative failure is minimal (52.2\%). Regarding job-placement with a reduced working week, the analysis shows that the maximal cumulative failure is very much peculiar to three cohorts: "1957-1966", "1967-1976", and "1977-1986" (73.2\%-79.1\%). However, a factor of belonging to an entrance cohort has an admitted influence on transition to this or that status in the labour market. As concerns employment through employment services, the analysis shows that the three latest entrance cohorts ("1982-1991", "1992-2001", "20022014") have the maximal cumulative failure. On the other hand, the probability of being employed in the general labour market is even higher for all the entrance cohorts than employment through employment services. Likewise, cumulative failure is the highest for two entrance cohorts: "19721981" and "1982-1991". Comparatively, the cumulative failure of job-placement with a reduced working week is maximal for the two latest cohorts ("2002-2014" and "1992-2001").

Taking into account the hypothetical effects of belonging to a birth or entrance cohort, the analysis of transitions to labour market training offers diverse results. On the one hand, the earliest birth cohort, "1935-1946", is exceptional in this case as the cumulative failure for this cohort is maximal. On the other hand, concerning transitions from unemployment to economic inactivity, the analysis shows that the maximal cumulative failure is very much peculiar to the cohorts "1967-1976", "1977-1986" and "1935-1946". It is to be expected, however, that earlier cohorts ("1935-1946", "19471956" and "1957-1966") realize more transitions from unemployment to unemployment pension. Comparatively, transitions from unemployment to labour market training essentially differ depending on entrance cohort membership. Thus, the maximal cumulative failure occurs for the two marginal entrance cohorts ("1952-1961" and "2002-2014"). Concerning transitions from unemployment to economic inactivity, the maximal cumulative failure ensues for the two entrance cohorts "1992-2001" and "1952-1961". Finally, the maximal cumulative failure for completion of an unemployment period due to reasons other than those studied occurs with a higher share of probability for the cohort "2002-2014". The maximal cumulative failure to realize transitions to unemployment pension exist for such entrance cohorts as "1962-1971" and "1952-1961".

When analysing the same tendencies for different birth cohorts, we find that the probability of being employed through employment services is higher for the cohort "1977-1986", considering the three, six, 12 and 24 month periods of observation. At the same time, while the probability of being placed in a job after three months' unemployment is higher for birth cohorts "1967-1976" and "19771986 ", with time this probability increases for all cohorts to the same rate - greater than $70 \%$ - except for the cohort "1977-1986". On the other hand, while the probability of being placed in a job with a reduced working time after three months' unemployment is higher for cohorts "1947-1956" and "1957-1966", with time this probability increases also for other cohorts, such as "1977-1986". Concerning other statuses that do not directly concern employment of unemployed immigrants, the 
tendency towards later allocation to labour market training (12-24 months) is typical for all cohorts. The same trend is typical for transitions from unemployment to economic inactivity (leaving the labour force). The most significant difference in this regard exists for the cohorts "1935-1946" and "1947-1956". Finally, as in two previous cases, the probability of moving to unemployment pension also increases after the first year in unemployment. It is essential, however, to note that the two cohorts "1957-1966" and "1977-1986" differ from other cohorts in this case.

This analysis of the tendencies arising from the position of belonging to this or that entrance cohort offers grounds upon which to assert that immigrants from later entrance cohorts ("1992-2001" and "2002-2014") have a greater chance of being employed through employment services. At the same time, it is more typical that immigrants from earlier entrance cohorts are slightly more likely to find a job ("1952-1961" and "1962-1971"). As the analysis shows, hypothetically, the earlier an immigrant became unemployed, the greater chance he had to find a job in the general labour market. The difference between entrance cohorts can be rather essential in this case. On the other hand, another tendency testifies to a trend for immigrants from later entrance cohorts to be more likely to take up reduced working time. In contrast to ordinary job-placement, the later an immigrant became unemployed (later entrance cohort), the more likely, hypothetically, he is to be "part-time" employed.

Regarding the statuses that do not concern direct job-placement, the general tendency suggests that transitions from unemployment to labour market training intensifies only after 12 months in unemployment and has varying significance for different cohorts (for example, for "1982-1991" and "1992-2001"). On the other hand, immigrants from the earliest entrance cohort ("1952-1961") are more likely to move from unemployment to economic inactivity than immigrants from recent cohorts. With time, this difference intensifies, in fact. The same tendency is observed when immigrants move to unemployment pension. The difference between cohorts in this case is rather essential - immigrants from the earliest entrance cohort have a higher probability of ending an unemployment period by movement to unemployment pension.

\section{Discussion and conclusions}

The objective of this study was to analyse the labour market transitions of immigrants out of unemployment. The novel contribution of this research consists in its multidimensionality and original approach to analysing labour market integration, as well as the fact that most of the study subjects primordially obtain a notion of distinction during the integration processes. Supposing that labour market integration implies a long-term period of adjustment to changing conditions, immigrants follow various trajectories of changing labour market statuses; this process can even have a lifelong character. Employment policy measures or training/retraining programmes are effective for final job-placement as a constituent part of a plan of complex adaptation and integration of unemployed populations into the labour market. On the other hand, the time period of unemployment and probability of staying in this status essentially differs depending on the status to which a transition occurs, as well as the time of completion of unemployment. Transitions to employment have a periodic, wave-like character and, over time, the probability for job-placement to one of the studied forms of employment essentially decreases.

Following multiple studies in the sphere of transitions out of unemployment spells, we estimated real-time determinants of completion of unemployment periods. We came to the conclusion that time constraints of completed unemployment periods essentially differ depending on the reasons for termination of unemployment periods. In the case of the Finnish labour market, the integrative capacity of the labour market, as directed towards providing the population with more transitions into employment, realizes a specific characterization. Taking into account completed unemployment periods and realized transitions from unemployment to other statuses, only $17.7 \%$ of unemployed persons are employed in the general labour market, whereas $46 \%$ are hired on part-time employment (reduced working week) during the period between seven and 12 months in unemployment. Comparatively, $34.4 \%$ of unemployed persons are employed in the general labour market, whereas $21.9 \%$ are hired on a part-time basis (reduced working week) during the period between 13 and 24 months in unemployment. Furthermore, the integrative capacity of the labour 
market becomes apparent in the form of transitions from unemployment to specific statuses such as, for example, participation in employment policy measures, labour market training or economic inactivity. In this case, the integrative capacity is realized through the participation of the unemployed population in subsidized employment measures or labour market training. For example, on average, $23 \%$ are employed through employment services during the period between seven and 12 months, while $18.3 \%$ are so employed during the period between 13 and 24 months. These data well demonstrate the extension and significance of active labour market measures.

Additionally, taking into account the dimension of the integrative capacity of the labour market as a mechanism of realized exclusionary transitions or transitions to economic inactivity, it is typical that, on average, $9.66 \%$ of the unemployed move out of the labour market (including those who interrupt unemployment periods for unknown reasons or move to unemployment pension). To explain the possible reasons for completion of unemployment for such unknown reasons, one can turn to some historical-economical evidence of changing unemployment in Finland. One reason might be that the possible job-placement of unemployed people is reported only to institutions that pay unemployment benefits, but not to employment services where unemployed people are registered as "unemployed." Unemployed people can thus remain registered as "completed an unemployment period for an unknown reason," because the register does not contain information about employment activity that an unemployed person finds without assistance from the employment service. According to our study, the greatest share of unemployed people find a job in the general labour market; however, the following categories of unemployed people admittedly move to long-term leave or retirement [2, 14, 18, 28, 29].

Besides general verification of time constraints of completed unemployment periods, we tested whether individual characteristics of unemployed people potentially affect the time of completion of unemployment and the exit states to which transitions from unemployment are realized. Following multiple existing empirical studies using discrete-time hazard models on the topic of transitions out of unemployment spells, we prove that transitions are strongly determined by the gender, age and education of immigrants, and the time of their entry into the labour market in Finland. Thus, following Alba-Ramírez et al. [3], who find that the probability of being recalled to new employment is higher for women, older people and for more qualified persons, we come to the conclusion that the probability of employment in the general labour market is almost the same for men as for women, while the probability is higher for immigrants having secondary education and a bachelor's degree and full employment occurs with almost the same share of probability for all the studied birth cohorts.

Contrary to Güell and Petrongolo [11], who find that the likely role of workers' outside options is most clearly visible when estimating separate conversion rates from unemployment to employment by education, as conversion rates are lower and more steeply increasing with tenure on temporary jobs for the less-skilled, we cannot estimate effects of unemployment duration on temporary or permanent jobs. However, we do come to the conclusion that transitions out of unemployment to employment are strongly education-determined. Coherent with Alba-Ramírez et al. [3], we find that the unemployment duration dependence differs according to the route of exiting unemployment. Finally, in accordance with Böheim and Taylor [7], who reveal that part-time employment is a more common destination state from unemployment for women than for men, we also find that transitions to part-time employment are more peculiar to women than to men, even though difference in this regard is not so essential.

Based on the discrete-time event history models, Gesthuizen and Wolbers [10] explain the observed trends in education-specific transition rates to re-entry into employment from unemployment or inactivity. Their results prove the tendency for the more highly educated, who no longer have access to the best positions, to try to find a job further down the job queue, thereby replacing the lesser educated and pushing them towards ever lower skilled jobs and, ultimately, nonemployment (unemployment and inactivity). We find that employment through employment services is more probable for immigrants with primary education, lower secondary education or doctoral degrees. With regard to transitions from unemployment to economic inactivity, the 
probability of realizing such transitions is hypothetically higher for immigrants having short-cycle tertiary education, upper secondary education or a doctoral degree. In general, the education factor is not a distinctive feature of transitions out of unemployment spells.

Contrary to Wolbers [31], who finds that the least well-educated employees have a higher risk of becoming unemployed than better-educated workers, we find that better-educated immigrants have a greater chance of remaining in unemployment by comparison to less educated immigrants. Also contrary to Wolbers [31], who posits that the increase of opportunities for work at the beginning of a period of unemployment is greater where the individual's educational level is higher, we come to contradictory conclusions. We find that university graduates face a greater risk of unemployment than vocationally educated graduates, although, in theory, the former should occupy the best positions in the job queue. According to our findings, individuals with an education that is more oriented towards the labour market (occupationally specific or vocational education), have a lower probability of becoming unemployed than those with a more general education.

In general, our research contributes to the dynamic approach to an analysis of labour market integration for a specific group of a work-capable population, specifically labelled as "immigrants". The approach undertaken in this research has a dualistic "descriptive-dynamic" character because integration is understood as a never-ending process, which is conditioned by a time period of longterm existence and a context of solitary action. As every scientific work encounters challenges, this research has not avoided the pre-existing challenges of such investigations. This precondition also determines the nature of the methodological background for the research in usage of such methods as discrete-time survival models.

Through this research, we argue that the nature of labour market integration is determined by various resources of a macro character. Based on the overall regularities of the existence of transitional labour markets, we argue that the integration of an immigrant labour force can be described by reference to institutionalization of transitions, risks and outcomes of transitions. The specificity of transitions between statuses in many respects depends on the specific integrative capacity of the Finnish labour market. On the other hand, taking into account the societal nature of labour market integration, this process is admittedly conditioned by the function, action, orientation and motivation of the immigrants as individuals. Finally, in many respects, the normative borders of legislation in conformity with a specific immigrant labour force and the existence of labour market segmentation in the Finnish labour market condition the specificity of labour market integration. This mainly concerns marginalization, stigmatization, pre-entry discrimination and the dualism of the labour market with regard to an immigrant labour force.

Trajectories of labour market integration are rather multifarious for immigrants with different backgrounds and can be explained by reference to age discrimination in the labour market, especially for young and old immigrants, gender discrimination, mostly concerning women, and the significance for the Finnish labour market of immigrants' educational backgrounds. All these factors give rise to new turns of discussion about the significance of stability and heterogeneity of transitions as dependent on the significance of specific patterns of sequences of transitions, especially for an immigrant population, which is initially in a more marginalized position that the native population. In this paper, we do not compare unemployment spells of immigrants with their analogues among the native population of Finland. This is undoubtedly a disadvantage of this research. However, the results are full of innovative content.

By means of large representative data, we prove that the integration of immigrants is a rather complicated and drawn-out process. We attempt to estimate this process as a discrete one. On the other hand, the timescales of activity of unemployed immigrants based on a dynamic approach through analysis of sequences of transitions from unemployment allow for the estimation of longterm careers of the unemployed from a lifelong perspective. The interconnection of time and space can be explored in terms of the participation of unemployed immigrants in cycles of unemployment through time, as well as in terms of the transformation of the employment system in Finland itself. Thus, any social transition is considered as a movement through space. Social interaction from this point of view is understood as the "coupling" of paths in social encounters; it emphasizes the 
coordination of movement through time and space in social activity, as the coupling of a multiplicity of paths or trajectories.

Supplementary Materials: The following are available online at www.mdpi.com/link: database used in the analysis.

Author Contributions: Oxana Krutova conceived and designed the experiments, performed the experiments, analyzed the data, contributed analysis tools, wrote the paper. Tapio Nummi conceived and designed the experiments, analyzed the data, contributed analysis tools.

Conflicts of Interest: The authors declare no conflict of interest. The founding sponsors had no role in the design of the study; in the collection, analyses, or interpretation of data; in the writing of the manuscript, and in the decision to publish the results.

\section{Appendix A}

Table A1. Description of variables used in the analysis.

\begin{tabular}{|c|c|}
\hline Variable & Description of variable (in parentheses - code of variables in an equation) \\
\hline case & id-number of unemployment periods $(i)$ \\
\hline months & time in month until unemployment period ends (months) \\
\hline event & $\begin{array}{l}\text { dummy variable for general completing unemployment periods ( } 0 \text { : censoring, } 1 \text { : failure) } \\
(y)\end{array}$ \\
\hline event_1 & $\begin{array}{l}\text { dummy variable for completing unemployment periods for exit state } 00 \text { "Employed } \\
\text { through employment services" ( } 0 \text { : censoring, } 1 \text { : failure })\left(y_{l}\right)\end{array}$ \\
\hline event_2 & $\begin{array}{l}\text { dummy variable for completing unemployment periods for exit state } 01 \text { "Employed in the } \\
\text { general labour market" }(0 \text { : censoring, 1: failure })\left(y_{2}\right)\end{array}$ \\
\hline event_3 & $\begin{array}{l}\text { dummy variable for completing unemployment periods for exit state } 02 \text { "On reduce } \\
\text { working week" ( } 0 \text { : censoring, } 1: \text { failure })\left(y_{3}\right)\end{array}$ \\
\hline event_4 & $\begin{array}{l}\text { dummy variable for completing unemployment periods for exit state } 03 \text { “Job-placed itself" } \\
(0 \text { : censoring, } 1 \text { : failure })\left(y_{4}\right)\end{array}$ \\
\hline event_5 & $\begin{array}{l}\text { dummy variable for completing unemployment periods for exit state } 04 \text { "In LM training" } \\
(0 \text { : censoring, } 1 \text { : failure })\left(y_{5}\right)\end{array}$ \\
\hline event_6 & $\begin{array}{l}\text { dummy variable for completing unemployment periods for exit state } 05 \text { "Outside the } \\
\text { labour force" }(0 \text { : censoring, } 1 \text { : failure })\left(y_{6}\right)\end{array}$ \\
\hline event_7 & $\begin{array}{l}\text { dummy variable for completing unemployment periods for exit state } 06 \text { "Another reason" } \\
(0 \text { : censoring, } 1 \text { : failure })\left(y_{7}\right)\end{array}$ \\
\hline event_8 & $\begin{array}{l}\text { dummy variable for completing unemployment periods for exit state } 07 \text { "On } \\
\text { unemployment pension" }(0 \text { : censoring, } 1: \text { failure })\left(y_{8}\right)\end{array}$ \\
\hline reason & $\begin{array}{l}\text { categorical variable for completed unemployment periods according to one of eight } \\
\text { reasons: } 00 \text { "Employed through employment services", } 01 \text { "Employed in the general } \\
\text { labour market", } 02 \text { "On reduce working week", } 03 \text { "Job-placed itself", } 04 \text { "In LM } \\
\text { training", } 05 \text { "Outside the labour force", } 06 \text { "Another reason" and } 07 \text { "On unemployment } \\
\text { pension" }(z)\end{array}$ \\
\hline gender & dummy variable for two genders (1: male; 2 : female) $\left(x_{l i}\right)$ \\
\hline education & $\begin{array}{l}\text { categorical variable for educational levels ( } 0 \text { : Early education; 1: Primary education; 2: } \\
\text { Lower secondary education; 3: Upper secondary education; 5: Short-cycle tertiary } \\
\text { education; 6: Bachelor or equivalent level; } 7: \text { Master or equivalent level; } 8 \text { : Doctoral or } \\
\text { equivalent level; } 9 \text { : Not elsewhere classified) }\left(x_{2 i}\right)\end{array}$ \\
\hline birth cohort & $\begin{array}{l}\text { categorical variable for five birth cohorts }(1: 1935-1946 ; 2: 1947-1956 ; 3: 1957-1966 ; 4 \text { : } \\
1967-1976 ; 5: 1977-1986)\left(x_{3 i}\right)\end{array}$ \\
\hline entrance & $\begin{array}{l}\text { able for six entrance cohorts }(1: 1952-1961 ; 2: 1962-1971 ; 3: 1972-1981 \text {; } \\
: 1992-2001 ; 6: 2002-2014)\left(x_{4 i}\right)\end{array}$ \\
\hline
\end{tabular}

\section{References}

1. Addison, J.; Portugal, P. How do different entitlements to unemployment benefits affect the transitions from unemployment into employment? IZA Discussion Papers. 2007, 3016.

2. Alatalo, J.; Torvi, K. Joustoturva Suomen työmarkkinoilla: indikaattorit ja niiden tulkinta. TEM-analyyseja. 2009, 14, 1-103. 
3. Alba-Ramírez, A.; Arranz, J.; Muñoz-Bullón, F. Exits from unemployment: Recall or new job. Labour Economics. 2007, 14(5), 788-810.

4. Blau, D.; Riphahn, R. Labour Force Transitions of Older Married Couples in Germany. IZA Discussion paper series. 1998, 5 .

5. Bover, O.; Arellano, M.; Bentolila, S. Unemployment duration, benefit duration and the business cycle. The Economic Journal. 2002, 112, 223-265.

6. Bover, O.; Gómez, R. Another look at unemployment duration: exit to a permanent vs. a temporary job. Investigaciones Económicas. 2004, vol. XXVIII, núm. 2, mayo, 285-314.

7. Böheim, R.; Taylor, M. The search for success: do the unemployed find stable employment? ISER Working Paper Series. 2000, 2000-05.

8. Caliendo, M.; Tatsiramos, K.; Uhlendorff, A. Benefit duration, unemployment duration and job match quality: a regression-discontinuity approach. IZA Discussion Papers. 2009, 4670.

9. De Graaf, P.; Ultee, W. Labour market transitions of husbands and wives in the Netherlands between 1980 and 1986. The Netherlands' journal of social sciences. 1991, 27(1), 43-59.

10. Gesthuizen, M.; Wolbers, M. Employment transitions in the Netherlands, 1980-2004: Are low educated men subject to structural or cyclical crowding out? Research in Social Stratification and Mobility. 2010, 28, 437451.

11. Güell, M.; Petrongolo, B. How binding are legal limits? Transitions from temporary to permanent work in Spain. Labour Economics. 2007, 14, 153-183.

12. Hagen, T. Do Fixed-Term Contracts Increase the Long-Term Employment Opportunities of the Unemployed? ZEW Discussion Papers. 2003, 03-49.

13. Hämäläinen, K. Active labour market programs and unemployment: a macro econometric study (PhD dissertation). University of Warwick. 1998.

14. Hämäläinen, K.; Tuomala, J.; Ylikännö, M. Työmarkkinatuen aktivoinnin vaikutukset. Työ ja yrittäjyys. 2009, 7, 1-68.

15. Jolkkonen, A.; Kurvinen, A. Työvoiman kysynnän ja tarjonnan kohtaanto aluetasolla ja ESRhanketoiminnan merkitys - esimerkkinä Pohjois-Karjala. Työpoliittinen Aikakauskirja. 2012, 55(2), 46-63.

16. Kiander, J.; Pehkonen, J. Finnish unemployment: observations and conjectures. Finnish Economic Papers. 1997, 12, 94-108.

17. Kiander, J.; Vartia, P. The Great Depression of the 1990s in Finland. Finnish Economic Papers. 1996, 9, 72-88.

18. Laukkanen, E. Mitä työttömyyden päättymisen syyt kertovat julkisen työvoimapalvelun pitkästä linjasta? Työpoliittinen Aikakauskirja. 2012, 55(3), 6-19.

19. Measuring quality of employment: Country pilot reports. Geneva: United Nations Economic Commission for Europe. 2010.

20. Moisio, S.; Leppänen, L. Towards a Nordic competition state? Politico-economic transformation of statehood in Finland, 1965-2005. Fennia. 2007, 185(2), 63-87.

21. Müller, K.-U.; Steiner, V. Imposed benefit sanctions and the unemployment-to-employment transition: the German experience. Discussion papers. German Institute for Economic Research. 2008, 792.

22. Peltola, M. Työmarkkinasiirtymät Suomessa. Työllisyyden päättymisen jälkeinen työmarkkinasiirtymien dynamiikka vuosina 1995-1999. Valtion taloudellinen tutkimuskeskus, VATT-keskustelualoitteita. 2005, 360.

23. Räisänen, H.; Schmid, G. Transitional labour markets and flexicurity from the Finnish labour market point of view. Discussion paper. 2008, SP I 2008-108.

24. Räisänen, H.; Sardar, P. Virta-varanto - kaaviot TEM:n työnvälityksen tilastojärjestelmässä - käsitteitä, sovelluksia ja tulkintoja. TEM-analyyseja. 2014, 55, 1-28.

25. Sengenberger, W. Beyond the measurement of unemployment and underemployment. The case for extending and amending labour market statistics. International Labour Organization. 2011.

26. Steiner, V. Extended benefit entitlement periods and the duration of unemployment in West Germany. ZEW Discussion Papers. 1997, 97-14.

27. Tatsiramos, K. Unemployment insurance in Europe: unemployment duration and subsequent employment stability. IZA Discussion Papers. 2006, 2280.

28. Terävä, E.; Virtanen, P.; Uusikylä, P.; Köppä, L. Vaikeasti työllistyvien tilannetta ja palveluita selittävä tutkimus. Työ ja yrittäjyys. 2011, 23.

29. Työllistämistukien työllisyysvaikutukset. Valtiontalouden Tarkastusviraston Tarkastuskertomus, 136/54/05(112). 2005. 
30. Uhlendorff, A.; Zimmermann, K. Unemployment dynamics among migrants and natives. IZA Discussion Papers. 2006, 2299.

31. Wolbers, M. The effects of level of education on mobility between employment and unemployment in the Netherlands. European Sociological Review. 2000, 16(2), 185-200.

(C) 2016 by the authors; licensee Preprints, Basel, Switzerland. This article is an open access article distributed under the terms and conditions of the Creative Commons by Attribution (CC-BY) license (http://creativecommons.org/licenses/by/4.0/). 